\title{
A QUARTA EMENDA E O CONTROLE JUDICIAL DA ATIVIDADE POLICIAL: BUSCA E APREENSÃO E STOP AND FRISK NA JURISPRUDÊNCIA DA SUPREMA CORTE ESTADUNIDENSE
}

\author{
FOURTH AMENDMENT AND JUDICIAL REVIEW OF POLICE ACTIVITY: SEARCH AND \\ SEIZURE AND STOP AND FRISK IN US SUPREME COURT JURISPRUDENCE
}

\section{Gisela Aguiar Wanderley}

\begin{abstract}
Mestra em Direito, Estado e Constituição pela Universidade de Brasília - UnB (2017). Graduada em Direito pela UnB (2014). Juíza de Direito no Tribunal de Justiça do Estado de Minas Gerais (TJMG).

E-mail: giselaaw@gmail.com
\end{abstract}

Recebido em: 26/09/2017

Aprovado em: 13/08/2019

\begin{abstract}
RESUMO: Nos julgados mais recentes do Supremo Tribunal Federal e do Superior Tribunal de Justiça, verifica-se uma tendência transconstitucional no trato da temática atinente aos limites de validade do exercício do poder policial ante a tutela dos direitos individuais, mediante remissões a julgados de cortes estrangeiras na fundamentação de vários votos. Nesse contexto, com o objetivo de fornecer elementos para subsidiar uma compreensão mais profunda e um debate mais amplo sobre tais julgados, o trabalho se propõe a apresentar e a analisar os precedentes mais relevantes da Suprema Corte dos Estados Unidos da América a respeito dos limites impostos pela Quarta Emenda à Constituição estadunidense à prática da busca e apreensão (search and seizure) e, em particular, à prática da stop and frisk (abordagem e revista). Ao cabo, observa-se que há contínuo protagonismo da Suprema Corte estadunidense na fixação de critérios e requisitos para a validade da atividade das agências de law enforcement, o que pode lançar luz sobre novas possibilidades de aprimoramento do controle judicial da atividade policial no cenário brasileiro.
\end{abstract}

Palavras-chave: Busca e apreensão. Busca pessoal. Busca domiciliar. Quarta Ementa. Controle judicial da atividade policial.

ABSTRACT: On its most recent rulings on police activity legal boundaries, Brazilian Supreme Federal Court and Superior Court of Justice have followed a transconstitutionalist tendency. In this context, this paper aims to present and analyze United States Supreme Court most relevant precedents regarding searches and seizures and stops and frisks. It is then argued that the Supreme Court is a continuous protagonist on the task of setting criteria and requirement on the legality of law enforcement acts, which could shed light on new possibilities to enhance judicial review of police activity in Brazil.

Keywords: Search and seizure. Stop and frisk. Fourth Amendment. Judicial review of police activity.

SUMÁRIO: Introdução; 1. A Quarta Emenda à Constituição dos EUA; 1.1. Esfera de proteção: extensão do direito tutelado; 1.2. Mandado prévio; 1.3. Causa provável; 1.4. Consequências da violação do preceito: a inadmissibilidade das provas ilícitas (exclusionary rule); 2. A stop and frisk; 2.1. O caso Terry v. Ohio (1968); 2.2. Os casos-irmãos: Sibron v. New York e Peters v. Revista de Direito Brasileira | Florianópolis, SC | v. 24 | n. 9 | p.341-364 | Set./Dez. 2019 
New York (1968); 3. Precedentes posteriores da Suprema Corte; 3.1. Precedentes relativos à stop; 3.2. Precedentes relativos à frisk; 3.3. Precedentes ampliativos e desfuncionalização: da indefinição conceitual ao uso da stop and frisk como tática de policiamento preventivo; 4. A importância do controle judicial da atividade policial: visão da Suprema Corte e da doutrina estadunidenses; Conclusão; Bibliografia.

\section{INTRODUÇÃ̃ ${ }^{1}$}

As polícias modernas são caracterizadas pela autorização coletiva para o uso da força orientado ao exercício do controle social (BAYLEY, 2001, p. 20). Sua atuação, inevitavelmente, provoca o tensionamento cotidiano de direitos e liberdades dos cidadãos, o que a coloca em uma posição central na conformação do Estado Democrático de Direito. Por isso, a atividade policial precisa ser estritamente regulamentada e escrutinizada pelas instâncias de controle, entre as quais se inserem o Poder Judiciário e o Ministério Público.

Nesse passo, vale reconhecer que, entre as intervenções mais recorrentes no cotidiano policial, a busca domiciliar e a busca pessoal ("baculejo") são exemplos de medidas dotadas de notável frequência e de elevada relevância para a persecução penal. Tais intervenções, com efeito, trazem consigo a inevitável tensão entre direitos fundamentais e poder policial, e revelam-se tão relevantes quanto corriqueiras.

Apesar disso, a dogmática jurídica e a jurisprudência brasileiras são ainda pouco elaboradas quanto a esse particular. Há ainda bastante insegurança jurídica quanto aos requisitos, limites e finalidades que condicionam a legalidade de atos praticados no cotidiano do policiamento, tratados como "questões jurídicas de segunda ordem". Assim, questões básicas do dia-a-dia do policiamento, tais como quando, como e por que um cidadão pode ser abordado e revistado em via pública, são contempladas como questões estritamente técnicas (tático-operacionais), e não como questões genuinamente jurídicas.

Essa conjuntura gera incerteza em uma via de mão dupla: tanto ao policial preocupado com o escorreito cumprimento de suas atribuições funcionais, quanto ao cidadão interpelado pelo aparato policial e zeloso da observância de seus direitos. Nenhum dos dois tem elementos suficientes para concluir de forma clara e segura quanto à legalidade da intervenção que realiza ou à qual é submetido. Por evidente, tal insegurança jurídica fragiliza a cidadania, ao erodir a consciência dos direitos fundamentais sobre os quais se funda a ordem constitucional-democrática inaugurada pela Constituição de 1988.

Diante de tal cenário, é curioso notar que o Supremo Tribunal Federal (STF) e o Superior Tribunal de Justiça (STJ) têm enfrentado vários casos relativos à validade de intervenções policiais. Naqueles de maior complexidade, tais cortes têm fundamentado as decisões não só no direito nacional, mas também no direito comparado e em precedentes de cortes estrangeiras sobre temáticas análogas. Trata-se de tendência do transconstitucionalismo, como aponta Neves (2009) ${ }^{2}$.

Nessa empreitada, os precedentes da Suprema Corte dos Estados Unidos da América (EUA) têm assumido particular destaque na jurisprudência dos tribunais de superposição brasileiros $^{3}$. Assim, exemplificativamente, no julgamento do RE 603.616, dotado de repercussão

\footnotetext{
${ }^{1}$ Este artigo é produto de adaptação de capítulo da dissertação de mestrado da autora.

${ }^{2}$ A tendência transconstitucionalista se espraia para temáticas diversas do direito processual penal. Como exemplo mais recente e proeminente, pode-se citar a execução provisória da pena após acórdão condenatório de segunda instância, enfrentada no julgamento do Habeas Corpus 126.292 e da Medida Cautelar nas Ações Declaratórias de Constitucionalidade 43 e 44. Sobre o tema, ver MARQUES (2017) e SUXBERGER; AMARAL (2017).

${ }^{3}$ Neste artigo, opta-se pelo uso da referência bibliográfica das decisões estadunidenses a partir do padrão de citação vigente nos EUA, consistente na identificação do nome do caso, seguido do número do volume da publicação, do nome do repositório, do número da página e do ano de publicação da decisão entre parênteses. V.g.: Miranda v. Arizona, 384 US 436 (1966). Nesse exemplo, "US" é a abreviatura para o meio de publicação (United States Reports), o primeiro Revista de Direito Brasileira | Florianópolis, SC | v. 24 | n. 9 | p.341-364 | Set./Dez. 2019
} 
geral, o STF fixou a tese de que a entrada forçada em domicílio pela polícia, sem mandado judicial, só é lícita quando amparada em fundadas razões que indiquem que dentro da casa ocorre situação de flagrante delito ${ }^{4}$. Para tanto, no voto condutor do Min. Relator, Gilmar Mendes, foram citados os casos Amos v. United States (1921) e Johnson v. United States (1948), relativos ao controle judicial da atividade policial e temas conexos.

Paralelamente, no julgamento do RHC 51.531 pelo STJ, reputou-se ilegal o acesso a dados constantes de aparelho celular do indivíduo preso em flagrante sem que haja autorização judicial prévia para tanto ${ }^{5}$. No voto-vista proferido pelo Min. Rogerio Schietti Cruz, citou-se o caso Riley v. California (2014), no qual a Suprema Corte dos EUA analisou situação parecida e concluiu pela necessidade de mandado judicial para acesso aos dados de celular de preso pelos policiais, por força do direito à privacidade. Já no voto-vista da Ministra Maria Thereza de Assis Moura, há referências a julgados da Suprema Corte do Canadá e do Tribunal Constitucional da Espanha.

$\mathrm{O}$ recurso às decisões da Suprema Corte estadunidense, de fato, fornece um rico arsenal de elementos e fundamentos para o aprofundamento do debate sobre os limites e condições do poder policial no Estado Democrático de Direito e, especialmente, sobre o papel do controle judicial como forma de coibição do abuso do poder policial. No direito estadunidense, com efeito, os requisitos de validade das buscas e apreensões (searches and seizures) também constituem questão tormentosa e polêmica, e que não escapa ao escrutínio do Poder Judiciário e da dogmática jurídica: verificam-se reiterados esforços de racionalização jurídica da prática de tais atos policiais.

Com efeito, desde a ratificação da Bill of Rights (1791), a Suprema Corte estadunidense tem capitaneado discussões multifacetadas sobre as condições de validade de buscas e apreensões, balizando os limites e prerrogativas dos órgãos de law enforcement. Assim, mais recentemente, o controle judicial da stop and frisk (abordagem e revista) na cidade de New York chegou a se tornar tópico dos debates das eleições presidenciais de $2016^{6}$.

Em tal contexto, revela-se oportuno aprofundar o estudo quanto ao tratamento dado pelo direito estadunidense à questão da validade de buscas e apreensões, com o objetivo de aprofundar e diversificar as reflexões sobre o tema no cenário brasileiro. Nesse ensejo, ante a escassez de estudos jurídicos sobre o tema e ante a atual tendência transconstitucional do STF e do STJ, este trabalho se propõe a apresentar e analisar os principais precedentes da Suprema Corte dos EUA sobre busca e apreensão, aí incluída a polêmica stop and frisk.

Para tanto, primeiramente, (1) apresenta-se a Quarta Emenda à Constituição estadunidense e os requisitos por ela impostos a uma busca e apreensão. Na sequência, (2) abordase o caso Terry v. Ohio (1968), pioneiro na definição do conceito e dos requisitos de validade de uma stop and frisk, encarada como uma espécie de busca e apreensão dotada de requisitos próprios. Após, apresentam-se precedentes subsequentes da Suprema Corte em que requisitos fixados no caso Terry foram reanalisados por perspectivas distintas, bem como aborda-se a reação da doutrina a tais julgados. Após, (3) analisa-se a desfuncionalização da stop and frisk em seu uso como tática de policiamento preventivo e reflete-se sobre a importância do controle judicial das práticas

\footnotetext{
número (384) é o número do volume, o segundo número (436) é a página inicial em que se inicia a transcrição do caso (se a citação de trecho específico, constará o número da página em que está o trecho) e entre parênteses está o ano de publicação (1966). Pelo sistema sugerido pela ABNT, a referência seria: Miranda v. Arizona, in United States Reports, n. 384, 1966, p. 436 ss. Quanto às decisões de outras cortes, indica-se o meio de publicação e, antes do ano, a corte julgadora. V.g.: United States v. Esieke, 940 F.2d 29 (2d Cir. 1991).

${ }^{4}$ STF, RE 603.616, Rel. Min. Gilmar Mendes, Tribunal Pleno, julgado em 05/11/2015, DJe 9/5/16

${ }^{5}$ STJ, RHC 51.531/RO, Rel. Min. Nefi Cordeiro, Sexta Turma, julgado em 19/04/2016, DJe 9/5/16

${ }^{6} \mathrm{O}$ candidato republicano eleito, Donald Trump, defendeu que os requisitos mais rígidos impostos na decisão do caso Floyd, et al v. City of New York, et al (2013) teria levado à diminuição de stops and frisks e a aumento de homicídios na cidade de New York. De outra parte, a candidata democrata, Hillary Clinton, aludiu a dados oficiais (disponíveis em: http://www.nyc.gov/html/nypd/downloads/pdf/crime_statistics/cs-en-us-city.pdf) que indicavam que, no período de decréscimo de stops and frisks, houve redução de homicídios na cidade.
}

Revista de Direito Brasileira | Florianópolis, SC | v. 24 | n. 9 | p.341-364 | Set./Dez. 2019 
policiais. Espera-se, ao fim, (4) lançar luz sobre as possibilidades do controle judicial das práticas policiais, ainda um tanto inexploradas no cenário brasileiro.

\section{A QUARTA EMENDA À CONSTITUIÇÃO DOS EUA}

O principal referencial normativo do direito estadunidense para o exame da validade de atos estatais restritivos da liberdade e da privacidade individuais consiste na Quarta Emenda à Constituição dos EUA, integrante da Bill of Rights de 1791. Tal dispositivo constitucional garante a proteção do indivíduo em face de buscas, detenções e apreensões (searches and seizures) desarrazoadas, e determina, em síntese, que buscas e apreensões realizadas em face do indivíduo, tanto sobre sua pessoa (corpo), como sobre seu patrimônio (bens móveis e imóveis), requerem mandado prévio, fundado em causa provável (probable cause) ${ }^{7}$. É o seu teor: "O direito das pessoas de estarem seguras em suas pessoas, casas, documentos e demais pertences em face de buscas e apreensões desarrazoadas não pode ser violado, e nenhum mandado o pode infringir, salvo quando calcado em causa provável, fundamentado por juramento, e descritos particularmente o local a ser revistado e as pessoas ou coisas a serem apreendidas" (tradução livre).

Quanto às exigências de mandado e causa provável, pode-se sintetizar introdutoriamente que o mandado deve ser expedido por autoridade independente e imparcial ${ }^{8}$ e que a causa provável está configurada se os fatos conhecidos são suficientes para garantir a um indivíduo de razoável cautela que um crime está sendo cometido9.

A interpretação conferida à Quarta Emenda foi, contudo, objeto de mudanças significativas conforme as mudanças sociais, políticas, econômicas e mesmo tecnológicas vivenciadas nos EUA desde a sua ratificação, as quais se refletem em tendências de enrijecimento ou flexibilização de seus requisitos. Assim, é pertinente traçar um panorama de alguns dos precedentes da Suprema Corte relativos a essa previsão constitucional, entre os quais se destacam aqueles relativos à extensão do direito tutelado, aos requisitos do mandado e da causa provável, e às consequências da violação do preceito.

\subsection{Esfera de proteção: extensão do direito tutelado}

Para a Suprema Corte, o propósito básico da Quarta Emenda, ao proibir buscas e apreensões desarrazoadas, é o de salvaguardar a privacidade e a segurança dos indivíduos em face de intervenções arbitrárias de agentes estatais. Reconhece-se que o indivíduo possui o direito de só ter a sua privacidade invadida em circunstâncias limitadas e determinadas, ainda que a intervenção estatal não configure uma intrusão hostil ${ }^{10}$.

Nesse passo, quanto à extensão do direito tutelado pela Quarta Emenda, o entendimento da Suprema Corte, consolidado desde 1967, é o de que esse dispositivo protege a "razoável expectativa de privacidade" (reasonable expectation of privacy) ${ }^{11}$. A Corte supera então a noção

\footnotetext{
7 Esse preceito já havia sido prestigiado tanto na Maryland Declaration of Rights (1776), quanto na Virginia Declaration of Rights (1776), que proibiam a concessão de mandados judiciais de busca e apreensão de caráter genérico e desprovidos de causa provável. No mesmo sentido: North Carolina Declaration of Rights (1776), art. XI; Pennsylvania Constitution (1776), art. X; Massachusetts Constitution (1780), pt. I, art. XIV.

${ }^{8}$ Johnson v. United States 333 U.S. 10 (1948); Coolidge v. New Hampshire, 403 U.S. 443 (1971)

${ }^{9}$ Brinegar v. United States 338 U.S. 160 (1948): "Existe causa provável se os fatos e circunstâncias conhecidos pelo policial, ou dos quais ele possui informação verossímil e confiável, são suficientes por si só para garantir a um homem de razoável cautela a crer que um crime está sendo cometido" (tradução livre).

${ }^{10}$ Camara v. Municipal Court, 387 U.S. 523 (1967).

${ }^{11}$ Katz v. United States, 389 U.S. 347 (1967). Há, porém, inúmeros precedentes posteriores que visam a balizar a incidência da expectativa. Em California v. Greenwood 486 U.S. 35 (1988), decidiu-se que não há expectativa de privacidade sobre o lixo deixado em via pública. Em Florida v. Riley 488 U.S. 445 (1989), decidiu-se que avistar entorpecentes em voo feito em altura em que há voos rotineiros não viola expectativa de privacidade. Em Kyllo v. United States 533 U.S. 27 (2001), decidiu-se que o uso de dispositivo térmico detector de radiação vermelha, capaz de Revista de Direito Brasileira | Florianópolis, SC | v. 24 | n. 9 | p.341-364 | Set./Dez. 2019
} 
de que o dispositivo se limita a evitar intrusão física no espaço privado (trespass doctrine) ${ }^{12}$. Para tanto, argui que a Quarta Emenda protege pessoas e não lugares ("protects people not places") ${ }^{13} \mathrm{e}$ que a proteção à privacidade não se restringe à proteção à propriedade. Assim, a Corte reconhece a proteção constitucional ampla ao direito à privacidade (right to privacy), tal como já propunham Warren e Brandeiss (1890) ao defender a tutela do direito de ser deixado em paz (right to be let alone).

\subsection{Mandado prévio}

Paralelamente à delimitação da extensão do direito protegido pela Quarta Emenda, a Suprema Corte tem analisado os requisitos do mandado prévio e da causa provável. Quanto ao mandado, entende a Suprema Corte que "o direito à privacidade foi considerado muito precioso para ser confiado à discricionariedade daqueles cujo trabalho é a detecção do crime e a prisão de criminosos. O poder é algo inebriante, e a história demonstra que não se pode confiar na polícia agindo por si só". Por isso, "ausente emergência grave, a Quarta Emenda interpõe um magistrado entre os cidadãos e os policiais"14, com a incumbência de avaliar a necessidade da violação da privacidade orientada à aplicação coercitiva da lei (law enforcement).

Contudo, há para a Corte algumas situações excepcionais em que o mandado prévio é dispensável. Uma primeira exceção decorre das situações de urgência: o mandado é dispensável se a intervenção policial é exigida sob circunstâncias urgentes (exigent circumstances), que não comportam a espera pela expedição do mandado ${ }^{15}$. Nesse sentido, ainda em 1925, em Carroll v. United States ${ }^{16}$, a Corte permitiu que buscas urgentes fossem feitas sem mandado, desde que indicada a causa provável. A exceção se aplica aos casos de abordagens a motoristas no trânsito

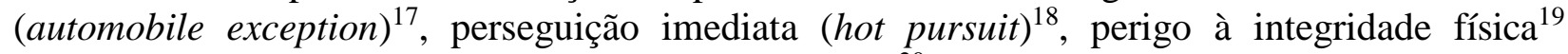
(emergency aid) e risco de fuga ou destruição de $\operatorname{provas}^{20}$.

A busca também pode dispensar mandado prévio se houver o consentimento do morador da casa ${ }^{21}$ ou do revistado. No entanto, para tal consentimento ser válido, deve ser livre e voluntário (e o ônus da prova é da acusação) ${ }^{22}$. Outra exceção é a plain view exception ("exceção da visão aberta"): se provas de um crime estiverem imediatamente visíveis, a apreensão não exige prévio mandado 23 .

visualizar a movimentação dos moradores de uma casa, viola a expectativa de privacidade. Em Riley v. California 573 U.S. (2014), decidiu-se que policiais não podem acessar smartphone de preso sem mandado.

${ }^{12}$ Ornellas v. United States 277 U.S. 438 (1928). Neste caso, a Corte julgou válida a inserção de escutas em telefones privados sem mandado, uma vez não havia violação ao espaço privado (domicílio). Entendeu-se que palavras são intangíveis e insuscetíveis de apreensão (seizure), razão pela qual a Quarta Emenda não as protegeria.

${ }^{13}$ Katz v. United States, 389 U. S. 351 (1967).

${ }^{14}$ McDonalds v. United States, 335 U.S. 455-456 (1948), tradução livre.

15 "Mandados são geralmente exigidos para revistar a casa de uma pessoa ou uma pessoa, a menos que a 'urgência da situação' torne os imperativos do law enforcement tão prementes que a busca sem mandado seja objetivamente razoável sob a Quarta Emenda”. Mincey v. Arizona, 437 U.S. 393-394 (1978) (tradução livre).

${ }^{16}$ Carroll v. United States, 267 U.S. 132 (1925)

${ }^{17}$ Florida v. White 526 U.S. 559 (1999)

${ }^{18}$ Warden v. Hayden, 387 U.S. 294 (1967); United States v. Santana, 427 U. S. 38 (1976)

${ }^{19}$ Brigham City v. Stuart 547 U.S. 398 (2006); Michigan v. Fisher 558 US 45 (2009)

${ }^{20}$ Ker v. California, 374 U. S. 23 (1963); Schmerber v. California, 384 U. S. 757 (1966)

${ }^{21} \mathrm{O}$ consentimento de um morador para a entrada na casa não é suficiente para dispensar o mandado, se outro morador se recusa expressamente a permitir a entrada. Cf. Georgia v. Randolph 547 U.S. 103 (2006).

${ }^{22}$ Schneckloth v. Bustamonte 412 U.S. 218 (1973)

${ }^{23}$ Coolidge v. New Hampshire, 403 U.S. 443 (1971); Arizona v. Hicks, 480 U.S. 321 (1987). Neste caso, um policial, em busca domiciliar motivada por disparo de arma de fogo, observou um aparelho de som sobre uma mesa e suspeitou, por este ser novo e moderno, que fosse produto de furto. Apreendeu alguns de seus componentes e, por pesquisa pelo número de série, confirmou a suspeita. Contudo, nos termos do voto do Justice Antonin Scalia, a Corte destacou que não havia prova diretamente visível do furto apta a configurar a plain view exception. 


\subsection{Causa provável}

Quanto à causa provável, também no caso Carroll $(1925)^{24}$, a Corte fixou que a causa provável está configurada se os fatos conhecidos pelo policial no momento da decisão de intervenção são suficientes para garantir a um "homem de razoável prudência e cautela" que um delito foi ou está sendo cometido ${ }^{25}$. Assim, é associada a uma "probabilidade considerável, uma possibilidade substancial, ou mesmo uma chance substancial” (GRANO, 1997, p. 8).

Trata-se, pois, de uma suspeita objetiva e individualizada, que confere ao cidadão o poder de controlar o cabimento da intervenção estatal: se a conduta do suspeito não é suficiente para constituir causa provável, então o Estado não possui o poder de proceder a uma busca (search) ou a uma detenção (seizure) (SUNDBY, 2004, p. 510). Daí ser a causa provável compreendida como uma garantia contra o abuso de autoridade, seja esta policial ou judicial.

Nesse passo, ausente causa provável, considera-se ilícita a busca calcada em mera intuição (hipótese em que se manifestam as convicções íntimas da autoridade, cedendo espaço a crenças discriminatórias ${ }^{26}$. Assim, em United States v. Di Re $(1948)^{27}$, ressaltou-se que a dificuldade do combate ao crime não é justificativa para a dispensa da causa provável. E, nessa mesma linha, em Henry v. United States (1959), a Corte reconheceu que a exigência de causa provável visa a coibir a "prática opressiva de autorizar o agente policial a deter e revistar baseado em suspeita" 28 . Rumores comuns, relatos ou mesmo "fortes razões para suspeitar" são então tidos como insuficientes para dar suporte a mandado de prisão ou busca e apreensão ${ }^{29}$. Conclui-se daí que a Quarta Emenda aponta que é preferível que um culpado não seja apenado a que cidadãos estejam continuamente sujeitados a prisões desarrazoadas ${ }^{30}$.

Portanto, uma vez condicionada à causa provável, a validade de uma intervenção policial não depende da obtenção de provas pelo agente após a busca/detenção, mas sim de fatos prévios que deem fundamento à busca/detenção e indiquem a probabilidade razoável de ocorrência de crime $^{31}$. Por isso, vale acrescentar que a Quarta Emenda protege não só o cidadão, mas, também, concomitantemente, o policial: ausente causa provável, a busca será inválida, ainda que tenha por resultado a apreensão de prova contra o revistado; por outro lado, fundada em causa provável, a busca, ainda que feita em um inocente, não renderá sanção ao policial.

\subsection{Consequências da violação do preceito: a inadmissibilidade das provas ilícitas (exclusionary rule)}

Uma das mais controversas questões analisadas pela Suprema Corte se refere às consequências da violação da Quarta Emenda por policiais nos casos em que o ato inconstitucional permite a obtenção de provas da prática de crime.

\footnotetext{
${ }^{24}$ Carroll v. United States, 267 U.S. 132 (1925)

${ }^{25}$ Um importante marco inicial da discussão do tema é o caso Stacey v. Emery, 97 U. S. 642 (1878).

26“'Não é necessária prova para afirmar a culpa do investigado. Por outro lado, a boa-fé no comportamento do policial que efetua a prisão não é suficiente. A causa provável existe se os fatos e circunstâncias conhecidos pelo policial garantem a um homem prudente a constatação de que um delito foi ou está sendo cometido" (Beck v. Ohio, 379 U.S. 97, 1964, tradução livre). Cf. também Rios v. U.S., 346 U.S. 253 (1960).

${ }^{27}$ United States v. Di Re, 332 U.S. 581 (1948). Nesse caso, ressaltou-se que o mero comportamento passivo do suspeito em face da detenção (sem arguir inocência) não constitui causa provável.

${ }^{28}$ Henry v. United States 361 U.S. 100 (1959), tradução livre.

${ }^{29}$ Tal orientação é prévia à própria Quarta Emenda, v.g. Frisbie v. Butler, Kirby's Rep. (Conn.) 1785-1788, p. 213.

${ }^{30}$ Orientação flexibilizada em Terry v. Ohio (1968). Tema tratado a seguir.

${ }^{31}$ Johnson v. United States, 333 U. S. 10, 16-17 (1948). Tal aspecto foi destacado no RE 603.616 pelo STF.
} Revista de Direito Brasileira | Florianópolis, SC | v. 24 | n. 9 | p.341-364 | Set./Dez. 2019 
A esse respeito, ainda em 1914, no caso Weeks v. United States ${ }^{32}$, a Suprema Corte assentou a regra da exclusão da prova ilícita (exclusionary rule), segundo a qual a infringência às garantias constitucionais deve implicar o desentranhamento das provas obtidas por meios ilícitos dos autos do processo penal. Desde então, a efetividade à Quarta Emenda tem sido atribuída sobretudo à exclusionary rule (WILLIAMSON, 1982).

Nesse julgamento, reforçou-se entendimento que já havia sido fixado anos antes em Boyd v. United States $(1886)^{33}$ e reconheceu-se que, se elementos obtidos em buscas contrárias à Quarta Emenda pudessem ser utilizados como provas do crime, esse dispositivo perderia sua força normativa. Assim, afirmou-se que conquanto os esforços de investigação sejam louváveis, não devem ser realizados mediante sacrifício de direitos individuais, a serem devidamente garantidos por meio do controle judicial das práticas policiais ${ }^{34}$.

Contudo, tal entendimento se aplicou, inicialmente, apenas aos casos submetidos às cortes federais, relativos à persecução penal promovida pelos órgãos federais, pois a Quarta Emenda, integrante da Bill of Rights, regeria somente a relação entre os órgãos federais e os cidadãos, e não a relação entre os órgãos estaduais e os cidadãos ${ }^{35}$.

Assim, em 1949, em Wolf v. Colorado, a Corte decidiu que, nos casos estaduais, a exclusão da prova ilícita não é uma consequência necessária da constatação da ilicitude da busca, pois, por força do princípio federativo, cada Estado possui discricionariedade para determinar a consequência da violação à cláusula do devido processo legal ${ }^{36}$.

Nesse julgado, a Corte reconheceu que, no caso concreto, provas haviam sido obtidas pela polícia estadual com violação à Quarta Emenda, a qual, por sua vez, implicaria violação à cláusula do devido processo legal (protegida pela Décima Quarta Emenda ${ }^{37}$ ), esta sim aplicável à relação entre os cidadãos e os Estados. Porém, a Corte ponderou que o devido processo legal não requer a exclusão das provas ilícitas do processo, pois seria possível coibir a produção ilícita de provas por outros meios, como, por exemplo, a partir de maior rigor disciplinar e transparência do trabalho policial. Obtemperou-se, ainda, que a exclusão da prova não surtiria efeito nos casos de buscas ilegais que não dessem ensejo à apreensão de prova. Por outro lado, a exclusão poderia levar à absolvição de culpados e prejudicaria o "combate ao crime" 38 .

Essa orientação, contudo, pereceu em 1961, no julgamento do caso Mapp v. Ohio ${ }^{39}$, no qual a Corte determinou que a violação à Quarta Emenda deveria implicar, necessariamente - tanto nos casos federais, quanto nos casos estaduais -, a exclusão das provas ilícitas do processo (exclusionary rule), por força da due process clause (Décima Quarta Emenda).

Reconheceu-se, em primeiro lugar, que a não aplicação da exclusionary rule aos casos estaduais tornaria a Quarta Emenda uma promessa vazia e que a proteção a esse direito constitucional, por ser indispensável a um sistema de liberdade ordenada (ordered liberty), é um consectário do devido processo legal ${ }^{40}$. Em segundo lugar, ressaltou-se que a exclusionary rule

\footnotetext{
${ }^{32}$ Weeks v. United States, 232 U.S. 383 (1914)

${ }^{33}$ Boyd v. United States, 116 US (1886). Nesse caso, a Corte decidiu pela imprestabilidade de provas obtidas com base em mandado de exibição de documentos expedido com base em informações falsas. Reconheceu-se ofensa à Quinta Emenda, que protege o direito à não auto-incriminação, anulou a sentença e determinou novo julgamento.

34 Afirma-se que a não aplicação da exclusionary rule resultaria na insubsistência do direito tutelado pela Quarta Emenda, já reconhecendo a interdependência entre rights e remedies. Como esclarece Levinson (1999), a definição de um direito não raro incorpora medida (remedy) para efetivá-lo ou protegê-lo, o que implica que, no extremo, se nenhuma medida é concebida para garantir o direito, então este é inexistente.

${ }^{35}$ Olmstead v. United States, 277 U.S. 438 (1928).

${ }^{36}$ Cf. também Irvine v. California, 347 U.S. 128 (1954), em que se reiterou esse entendimento.

${ }^{37}$ Décima Quarta Emenda (1868): "Seção 1: [...] [N]enhum Estado, tampouco, privará qualquer pessoa da vida, da liberdade, ou da propriedade, sem o devido processo legal [...]” (tradução livre).

${ }^{38}$ Wolf v. Colorado 338 U.S. 25 (1949).

${ }^{39}$ Mapp v. Ohio, 367 U.S. 643 (1961)

${ }^{40}$ A Suprema Corte entende, a partir da teoria da incorporação seletiva, que são elementos do devido processo legal os direitos e garantias "implícitos no conceito de liberdade ordenada", cuja abolição equivaleria a uma violação a "um
} Revista de Direito Brasileira | Florianópolis, SC | v. 24 | n. 9 | p.341-364 | Set./Dez. 2019 
decorre do imperativo de integridade do sistema jurídico: uma ilicitude reconhecida na esfera administrativa ou civil em virtude de violação à Constituição não pode ser ignorada no processo penal. No ponto, salienta-se que nada pode destruir um governo tão rápido quanto a não observância de suas leis por ele próprio, em um atropelo ao fundamento de sua existência ${ }^{41}$. Por fim, destacou-se que a exclusionary rule apresenta significativo efeito dissuasório (deterrence) em relação à prática de ilegalidades pelos policiais.

Esse precedente não foi bem recebido pela opinião pública, pois se entendia que poderia prejudicar a repressão penal ao possibilitar a absolvição de culpados. Nas ruas chegaram a aparecer cartazes pedindo o impeachment do Chief Justice Earl Warren ${ }^{42}$ (KATZ, 2004). A Suprema Corte e o sistema criminal se tornaram então temas constantes nos debates para as eleições presidenciais de 1968, em que se elegeu o republicano Richard Nixon.

Cerca de sete anos depois, sobreveio o precedente Terry v. Ohio ${ }^{43}$. Neste, a exigência de causa provável e de mandado prévio para uma busca ou detenção foi abrandada. Nessa oportunidade, a Corte definiu requisitos menos rígidos para um tipo específico de abordagem policial, a "stop and frisk" (retenção e revista), a qual constituiria uma detenção (seizure) seguida de uma busca (search), porém de caráter menos gravoso e menos invasivo.

O caso Terry é interpretado como uma reação da Corte à péssima recepção social do precedente Mapp: os requisitos mais brandos para a validade da stop and frisk dificultariam o reconhecimento de sua ilicitude e, por conseguinte, também a exclusão de provas, amenizando o impacto do caso Mapp (SCHWARTZ, A., 1995) ${ }^{44}$. Assim, o precedente Terry foi ele próprio causador de intensa repercussão social e, desde então, as stops and frisks são objeto recorrente do estudo do processo penal estadunidense.

\section{A STOP AND FRISK}

\subsection{O caso Terry v. Ohio (1968)}

De acordo com o relatório dos fatos elaborado pelo Chief Justice Earl Warren, o caso concreto analisado em Terry v. Ohio era relativo aos seguintes fatos: um agente policial à paisana (McFadden) observou que, em uma rua pública, dois indivíduos (Terry e Chilton) percorriam um

princípio de justiça tão enraizado nas tradições e na consciência do nosso povo que é classificado como fundamental" Palko v. Connecticut 302 U.S. 325 (1937). Sobre o tema, cf. ISRAEL et al., 2012.

${ }^{41}$ Lembra-se, no ponto, trecho do voto vencido do Justice Louis Brandeis no caso Olmstead v. United States 277 US 485 (1928): "O decoro, a segurança e a liberdade demandam, igualmente, que as autoridades estatais sejam submetidas às mesmas normas de conduta que são dirigidas aos cidadãos. Em um governo de leis, a existência do governo estará sob risco se este deixar de observar a lei escrupulosamente. O nosso Governo é o poderoso, o onipresente mestre. Bem ou mal, ele orienta todo o povo pelo seu exemplo. O crime é contagioso. Se o Governo se torna um infrator da lei, ele convida à arnaquia. Declarar que, na administração da justiça criminal, os fins justificam os meios - declarar que o Governo pode cometer crimes com o objetivo de assegurar a punição de um determinado criminoso - atrairia um terrível castigo. Contra essa doutrina perniciosa esta Corte deve resolutamente contrapor-se." (tradução livre)

42 Earl Warren ocupou o cargo de Chief Justice entre os anos de 1953-1969 e até hoje é lembrado pelos precedentes de orientação liberal proferidos pela Suprema Corte sob a sua presidência, entre os quais se destacam os casos Brown v. Board of Education of Topeka 347 U.S. 483 (1954) e Miranda v. Arizona 384 U.S. 436 (1966). Baum (1987) nota que entre as décadas de sessenta e oitenta (1961-1980), pelas Cortes Warren (1953-1969) e Burger (1969-1986), foram proferidas 75 decisões de overruling, ou seja, em que precedentes anteriores foram superados. Por outro lado, a Corte Burger proferiu inúmeras decisões com interpretação restritiva (restrictive distinguishing) de precedentes da Corte Warren, mormente referentes aos direitos de acusados em casos criminais.

${ }^{43}$ Terry v. Ohio, 392 U.S. 1 (1968).

${ }^{44}$ Ainda, conforme registra Adina Schwartz (1995), o caso Terry foi apreciado em um período em que doutrina da "lei e ordem", o crescente medo da criminalidade, a discriminação racial e os protestos do movimento negro em prol de direitos civis circundavam os debates da campanha presidencial. 
idêntico trajeto, indo, voltando e fazendo pausas esporádicas para observar a janela de uma loja ${ }^{45}$. Os dois conversavam no fim de cada "ciclo", e, em um deles, encontraram-se com um terceiro indivíduo (Katz), que conversou algo com eles e saiu sorrateiramente. McFadden então suspeitou (embora sem elementos suficientes para constituir causa provável) que um assalto à mão armada ocorreria em breve.

Quando os três já deixavam a rua, dirigindo-se a local incerto, McFadden aproximou-se deles, identificou-se como policial e perguntou-lhes os seus nomes. Um dos suspeitos, Terry, murmurou algo inaudível em resposta ao policial, o que motivou este a agarrá-lo e a proceder a uma revista no exterior de suas vestimentas. Sentindo uma arma no bolso do casaco de Terry, ele ordenou aos suspeitos que entrassem em uma loja próxima e levantassem as suas mãos, colocandose contra a parede. O policial então removeu a pistola de Terry e revistou o exterior das vestes dos outros dois suspeitos. Sentindo uma arma no casaco de um deles (Chilton), apreendeu a pistola, e liberou o terceiro suspeito (Katz), que aparentemente não portava arma.

Fixadas tais balizas fáticas, a Corte reconheceu que McFadden realizou uma stop and frisk e agiu sem mandado e sem causa provável. A Suprema Corte, então, pela primeira vez, utilizou o termo "stop" - aqui traduzido como "retenção" - para definir uma abordagem policial coercitiva por meio da qual a liberdade ambulatorial é restringida brevemente para investigação no próprio local. Ademais, utilizou-se o termo "frisk" - aqui traduzido como "revista" - para definir a inspeção das vestes de um indivíduo com o objetivo de encontrar armas com as quais a integridade física do policial ou de terceiros pudesse ser vulnerada.

Para decidir se a atuação de McFadden foi lícita, a Corte principiou destacando que a Quarta Emenda proíbe detenções e buscas desarrazoadas (unreasonable searches and seizures), proibição essa que se aplica à stop e à frisk, pois tais atos constituem, respectivamente, espécies de detenção (seizure) e de busca (search ${ }^{46}$. Contudo, ponderou-se que a stop e a frisk têm baixo nível de invasividade e não exigem mandado, nem causa provável, mas sim requisitos menos rígidos vinculados ao parâmetro geral de razoabilidade extraído da Quarta Emenda.

Portanto, a Corte decidiu que, para realizar uma retenção (stop), o policial deve apresentar elementos objetivos que configurem suspeita razoável de que uma atividade criminosa está em andamento. A retenção, portanto, tem natureza investigativa (investigative stop). A revista (frisk), por sua vez, depende de suspeita razoável de que ele está armado e é perigoso para o policial ou terceiros, e sua extensão deve se limitar aos atos necessários para descobrir armas. A revista, portanto, tem natureza protetiva (protective frisk):

[S]e um policial observa uma conduta não usual, a qual o conduz a razoavelmente concluir, à luz de sua experiência, que atividade delitiva pode estar em andamento e que a pessoa com a qual ele está lidando pode estar armada e ser atualmente perigosa, e se no curso da investigação desse comportamento ele se identifica como policial e faz questionamentos razoáveis, e se nada nos estágios iniciais da abordagem servem para afastar o seu receio razoável pela sua segurança ou de outros, então ele está legitimado a, para a sua própria proteção e para a proteção dos outros presentes na área, a conduzir uma busca cuidadosamente limitada às vestes exteriores dessa pessoa, com o fito de descobrir armas que possam ser usadas para atacá-lo. Uma busca desse gênero é uma busca razoável sob a Quarta

\footnotetext{
${ }^{45}$ Tais fatos são controversos ao se comparar os relatos de McFadden em momentos distintos, em que ele vacila quanto ao número de vezes de percurso do trajeto e quanto à loja observada - inicialmente, alude a escritório de venda de passagens aéreas e, posteriormente, a joalheria (Cf. KATZ, 2004; SALEEM, 1997; AMAR, 2005). Porém, opta-se por apresentar os fatos como reconhecidos pela Corte, para clarificar as diretrizes jurídicas fixadas.

${ }^{46}$ Quanto à tradução, optou-se pela tradução de "stop" como "retenção" e não como "detenção", para diferenciar a espécie do gênero, assim como na língua inglesa. O mesmo quanto à tradução de "frisk" como "revista".
}

Revista de Direito Brasileira | Florianópolis, SC | v. 24 | n. 9 | p.341-364 | Set./Dez. 2019 
Emenda, e quaisquer armas apreendidas podem ser utilizadas como prova contra a pessoa da qual elas foram retiradas. ${ }^{47}$

Quanto aos conceitos de suspeita razoável e causa provável, esclareceu-se posteriormente que a suspeita razoável é requisito menos rigoroso que a causa provável em termos de quantidade e de confiabilidade dos fatos em que se embasa a crença de que o indivíduo está praticando um fato-crime ${ }^{48}$. De todo modo, destaca-se:

A despeito desse parâmetro menos rigoroso, a suspeita razoável deve estar fundada em fatos específicos e objetivos e em conclusões lógicas embasadas na experiência do policial. Ela não pode ser baseada na mera intuição (que possui 0 por cento de certeza) ou suspeita (que pode ter 10 por cento de certeza). A suspeita razoável está inserida entre a suspeita e a causa provável na hierarquia de certeza exigida para a polícia atuar legalmente. (HEMMENS; CARMEN, 2010, p. 66, tradução livre)

Por outro lado, no caso Terry, voto dissidente foi proferido pelo Justice Douglas, que entendeu que permitir uma stop and frisk com base em suspeita razoável implicaria conferir ao policial poderes maiores que aqueles conferidos aos próprios magistrados (os quais somente poderiam conceder mandados de detenção e busca com base em causa provável). Assim, o Justice Douglas opinou que tal flexibilização significaria uma opção por um caminho totalitário, em que a repressão ao crime é encetada em detrimento dos direitos individuais, e concluiu que policiais só poderiam efetuar stops and frisks sem mandado ante causa provável.

Diante de tais fundamentos, Wayne R. LaFave, Jerold H. Israel e Nancy J. King (2012) opinam que há três pontos centrais no caso Terry. O primeiro é a inédita constatação de que retenção (stop) do indivíduo na rua, mediante coação física ou ordem (explícita ou implícita) de parada, configura uma detenção (seizure) e de que uma exploração superficial das vestes exteriores do indivíduo (frisk) configura uma busca (search) - independentemente do rótulo ou denominação que se dê a tais atos, aos quais se aplica então a Quarta Emenda. O segundo é a adoção de um teste de balanceamento para a aferição da constitucionalidade de uma prática policial restritiva de liberdade não embasado no parâmetro da causa provável ${ }^{49}$. E o terceiro é a assertiva de que a exclusão da prova ilícita não seria eficaz para evitar violações às garantias constitucionais nos casos em que a polícia não tiver por objetivo a persecução penal ou estiver disposta a sacrificá-la a fim de atingir outros objetivos.

\subsection{Os casos-irmãos: Sibron v. New York e Peters v. New York (1968)}

Embora o precedente Terry v. Ohio seja considerado o julgado paradigmático sobre a prática da stop and frisk, a Suprema Corte, no mesmo dia (10 de junho de 1968), julgou, logo após o caso Terry, outros dois casos similares, em que dois réus sustentavam a ilicitude da abordagem que precedeu à apreensão de provas que os incriminavam.

Nesses dois casos, os acusados (Sibron e Peters) requeriam o reconhecimento da ilicitude de provas obtidas por policiais de New York (NY) a partir de stop and frisk. Para tanto, sustentavam a inconstitucionalidade de recente dispositivo de lei estadual - $\$ 180$-a do New York Criminal Procedure Code (1881), incluído em 1964 - que autorizava a "stop, question and frisk" pela polícia. Esse dispositivo foi invocado pelo Estado, em ambos os casos, como fundamento da validade das provas obtidas. Os casos foram julgados conjuntamente, sob o nome Sibron v. New

\footnotetext{
47 Terry v. Ohio, 392 U.S. 30-31 (1968), tradução livre.

${ }^{48}$ Alabama v. White, 496 U.S. 330 (1990), tradução livre.

${ }^{49}$ Tal como já havia ocorrido um ano antes em Camara v. Municipal Court, 387 U.S. 523 (1967).
} 
York, cuja opinião foi redigida também pelo Chief Justice Earl Warren ${ }^{50}$. No caso de Sibron, a Corte concluiu pela ilicitude das provas e, no de Peters, pela validade.

No primeiro caso, um policial em patrulha (Martin) observou Sibron (até então um desconhecido para Martin) conversando com seis ou oito pessoas que o policial sabia serem viciados em entorpecentes, por oito horas contínuas (16h-24h). Mais tarde, o policial viu Sibron entrar em um restaurante, com mais três indivíduos conhecidos por serem viciados em entorpecentes. Sibron sentou-se, pediu uma torta e um café. O policial abordou Sibron e chamouo para fora do restaurante, onde lhe disse "você sabe o que eu estou procurando". Sibron fez menção de pegar algo em seu bolso, momento em o policial alcançou esse bolso e retirou dele envelopes com heroína.

Ao analisar o caso ${ }^{51}$, a Suprema Corte registrou, em primeiro lugar, que há diferença entre uma abordagem policial voluntária (sem restrição à liberdade do abordado, que meramente coopera com o policial) e uma abordagem coercitiva (stop, decorrente de demonstração de autoridade que não deixa ao indivíduo a escolha de ignorar o policial $)^{52}$. Assim, quanto ao caso concreto, notou que não havia elementos suficientes para determinar se Sibron havia sido "retido" (stopped) pelo policial Martin no interior do restaurante.

Noutro giro, para aferir se a busca feita no bolso de Sibron foi válida, reputou-se necessário definir se tal ato configurou uma busca investigativa em procura de drogas (search), ou uma revista protetiva em procura de armas (frisk), conforme decidido em Terry. A Corte notou que a busca feita no bolso de Sibron não poderia ser classificada como protetiva (frisk), uma vez que o próprio policial admitiu que não possuía razão para acreditar que Sibron ocultasse arma e, mesmo que ele assim alegasse, a revista feita diretamente no bolso não seria compatível com essa justificativa. Destacou-se, pois, uma diferença relevante em relação ao caso de Terry: neste, o policial revistou a jaqueta de Terry, abaixo dos braços, onde poderia estar ocultada arma, ao passo que, no caso de Sibron, o policial revistou diretamente o bolso de Sibron, denotando que o intuito da busca não era o de autoproteção, mas sim o de investigação. ${ }^{53}$

A Corte, ainda, realçou que a frisk permitida em Terry não é uma busca com propósitos investigativos $^{54} \mathrm{e}$, ademais, não pode ser feita indistintamente, pois requer elementos que deem suporte razoável à inferência de que o indivíduo está armado ${ }^{55}$. Assim, quanto ao caso concreto, ocorreu uma busca investigativa (search), a qual precisaria de causa provável. Quanto ao ponto, a Corte notou que o policial Martin não ouviu nenhuma conversa, nem viu qualquer passagem de objetos entre Sibron e os usuários de entorpecentes. Destacou-se que, "até onde ele sabia, eles poderiam realmente "estar conversando sobre o Campeonato de Baseball", 56 . Nesse contexto, a

\footnotetext{
${ }^{50}$ Sibron v. New York, 392 U.S. 40 (1968). Na oportunidade, a Corte entendeu que seria um "exercício improdutivo" analisar se as "elásticas categorias" do § 180-a do NY Criminal Procedure Code seriam compatíveis com a Quarta Emenda, pois “a validade constitucional de uma busca sem mandado é proeminentemente o tipo de questão que só pode ser decidida à luz do contexto fático concreto do caso individual” (Sibron v. New York, 392 U.S. 56, 1968). A Corte aduziu então que o essencial não é avaliar a adequação da linguagem legal, suscetível de interpretações variadas, mas sim a conduta policial que ela autoriza, que não pode contrariar as limitações constitucionais. Assim, a Corte não analisou a constitucionalidade do $\S 180$-a do NY Criminal Procedure Code e limitou-se a avaliar se as abordagens atenderam à Quarta Emenda - e não à lei estadual.

51 Acusado pelo porte ilegal da heroína, Sibron apresentou pedido de exclusão da heroína dos autos (motion to suppress), a qual foi rejeitada pela corte de julgamento, que entendeu que o policial tinha causa provável para realizar a prisão e apreender a heroína. Em seguida, Sibron assumiu-se culpado (pleaded guilty). A rejeição do pedido de exclusão da prova foi mantida pela corte de apelações estaduais intermediária e depois pela Corte de Apelações do Estado de New York. Perante esta, o Estado defendeu a validade da busca com base no NY Criminal Procedure Code, o que foi aceito. Mas, ante a Suprema Corte, o District Attorney admitiu ter havido erro.

52 Sibron v. New York, 392 U.S. 63 (1968) (tradução livre).

${ }^{53}$ Sibron v. New York, 392 U.S. 65 (1968).

${ }^{54}$ A possibilidade de desvio de finalidade da medida já havia sido objeto de alerta por parte da doutrina quando da inclusão do § 180-a no NY Criminal Procedure Code (cf. SCHWARTZ, H., 1967, p. 461).

${ }^{55}$ Sibron v. New York, 392 U.S. 63-64 (1968) (tradução livre)

${ }^{56}$ Sibron v. New York, 392 U.S. 62 (1968) (tradução livre)
}

Revista de Direito Brasileira | Florianópolis, SC | v. 24 | n. 9 | p.341-364 | Set./Dez. 2019 
inferência de que Sibron estaria engajado no tráfico meramente porque ele conversou com usuários de entorpecentes não constituía causa provável para uma busca sem mandado incidental à prisão (search incident to arrest) ${ }^{57}$ : "a inferência de que pessoas que conversam com viciados estão envolvidas com o tráfico não constitui o tipo de inferência razoável requerida para embasar uma intrusão policial sobre a esfera pessoal de um indivíduo" ${ }^{\text {"58 }}$. Assim, a Corte concluiu que a busca violou a Quarta Emenda e determinou a exclusão das provas obtidas.

No caso Peters, um policial (Lasky), em seu apartamento, ouviu um ruído do lado de fora. Pela portinhola, avistou dois indivíduos (um deles Peters) movendo-se de modo furtivo na ponta dos pés pelo rol de entrada. Lasky chamou a polícia, vestiu-se e armou-se. Acreditando que eles estavam prestes a invadir o recinto para praticar um furto (burglary), saiu do apartamento e bateu bruscamente a porta, o que ensejou a fuga dos dois. Passou então a persegui-los e capturou Peters no rol de entrada do apartamento. Peters disse que estava visitando uma namorada, cujo nome se recusou a declinar, alegando que esta era casada. Lasky então revistou Peters e ao apalpar suas vestes sentiu um objeto sólido, que pensou que pudesse ser uma faca. Tratava-se, na verdade, de um recipiente com ferramentas para o furto (burglar's tools). Peters foi acusado pelo porte de artefato com o objetivo de cometer crime.

Ao analisar o caso ${ }^{59}$, a Suprema Corte ressaltou que a revista realizada pelo policial Lasky tinha o estrito objetivo de encontrar armas em posse de Peters e, ademais, foi realizada em uma situação em que havia causa provável, autorizativa de busca incidental à prisão, observando que seria "difícil conceber indícios mais fortes para uma prisão, próxima da observação visual da atividade criminosa flagrante" 60 . Assim, a Corte entendeu que a abordagem foi válida, pois, quando o policial alcançou Peters, ele o reteve com base em causa provável, o que inclusive autorizaria busca (investigativa) incidental à prisão.

\section{PRECEDENTES POSTERIORES DA SUPREMA CORTE}

A Quarta Emenda protege o direito das pessoas de estarem seguras contra buscas e detenções (searches and seizures) desarrazoadas e, assim, limita as circunstâncias de restrição da liberdade de um indivíduo antes da sentença condenatória. Essa garantia constitucional limita não apenas a restrição de liberdade operada sob a forma tradicional da "prisão" (arrest), mas também sob a forma de uma detenção temporária para propósitos de investigação ou interrogatório, designada genericamente como uma seizure ${ }^{61}$ (WILLIAMSON, 1982).

Logo após o julgamento dos casos Terry e Sibron, Wayne LaFave (1968) publicou artigo em que ressaltou que, antes desses precedentes, a ausência de diferenciação entre uma prisão (arrest) e uma retenção (stop) estava levando a uma flexibilização excessiva do conceito de causa provável, com o objetivo de validar retenções investigativas, de caráter menos intrusivo do que uma prisão. Nesse contexto, a delimitação de requisitos próprios para uma retenção investigativa

\footnotetext{
${ }^{57}$ Para a Corte, a busca incidental à prisão sem mandado e causa provável deve limitar-se à pessoa do preso e pertences sob alcance imediato. Trata-se da "Chimel rule" (cf. Chimel v. California, 395 U.S. 752 (1969)).

${ }^{58}$ Sibron v. New York, 392 U.S. 62 (1968) (tradução livre)

${ }^{59}$ Peters apresentou um pedido de exclusão da prova (motion to suppress), rejeitado pela corte de julgamento, que sustentou que a busca era justificada sob o $§ 180$-a do NY Criminal Procedure Code. Esse entendimento foi ratificado pela corte intermediária de apelações e pela Corte de Apelações de New York.

${ }^{60}$ Sibron v. New York, 392 U.S. 66 (1968) (tradução livre)

${ }^{61} \mathrm{O}$ termo seizure, constante da Quarta Emenda, abarca tanto atos restritivos da liberdade de pessoas como atos de retenção de objetos. Tal termo costuma ser traduzido como apreensão na língua portuguesa. Não obstante, no Brasil, o termo apreensão costuma ser usado para designar apenas a retenção de objetos, e raramente para designar atos restritivos da liberdade de pessoas. Por isso, neste trabalho, opta-se pelo uso de duas palavras na tradução do termo seizure, a depender do caso: usa-se a palavra apreensão para designar a retenção de coisas e a palavra detenção para designar o gênero atos restritivos da liberdade de pessoas. O termo prisão, por sua vez, é usado como tradução de arrest (espécie de seizure). Cf. WILLIAMSON, 1982.
}

Revista de Direito Brasileira | Florianópolis, SC | v. 24 | n. 9 | p.341-364 | Set./Dez. 2019 
(stop) no caso Terry teria o condão de deixar incólume o conceito de causa provável, a ser exigida com rigidez e vigor para a prática de uma efetiva prisão (arrest).

Assim, para LaFave (1968), a leitura conjunta dos casos Terry e Sibron fornece diretrizes para guiar o encontro entre policiais e cidadãos no espaço público, uma vez que, de um lado, elencam-se os caracteres de uma stop e de uma frisk - e assim as distingue de outras práticas policiais mais ou menos invasivas - e, de outro, definem-se as condições de validade de uma stop e de uma frisk. Aí estaria então um dos principais méritos da Suprema Corte no julgamento dos casos em tela.

Nesse sentido, para Hemmens e Carmen (2010), em poucas oportunidades a Corte foi tão clara quanto aos parâmetros a serem seguidos pela polícia na execução de um determinado ato. De fato, no caso Terry, a Corte objetivou definir um tipo específico de abordagem (stop and frisk) que, por ser breve e menos intrusiva, submeter-se-ia a requisitos menos rígidos, em exceção à exigência de causa provável e mandado constante da Quarta Emenda. Assim, identifica-se uma preocupação em não alargar demasiado os poderes de retenção e revista atribuídos aos policiais, mediante a delimitação dos atos de stop e frisk e de suas respectivas condições de validade. Essa preocupação da Corte em Terry reaparece em alguns julgados posteriores, nos quais limitam-se a extensão e as finalidades de uma stop e de uma frisk.

\subsection{Precedentes relativos à stop}

São relevantes os julgados da Corte em que se analisou a diferença entre um encontro de natureza voluntária (encounter) entre policial e cidadão e uma retenção de natureza coercitiva (stop) de um cidadão. O tema foi abordado pelo Justice Stewart em United States v. Mendenhall $(1980)^{62}$, o qual propôs uma regra geral:

Uma pessoa foi "detida", no sentido da Quarta Emenda, somente se, sob o ponto de vista de todas as circunstâncias relativas ao incidente, uma pessoa razoável acreditaria que ele não está livre para ir embora. Exemplos de circunstâncias que poderiam indicar uma detenção, mesmo se a pessoa não tentou ir embora, seriam a presença ameaçadora de vários policiais, a demonstração de uma arma pelo policial, algum contato físico da pessoa do cidadão abordado, ou o uso de linguagem ou tom de voz que indique que a obediência ao pedido do policial pode ser obrigatória. ${ }^{63}$

Entendeu-se, pois, que quando a abordagem policial provoca no cidadão a crença de que ele não está livre para ir embora, tal abordagem constitui uma retenção (stop). Tal regra foi resgatada em Florida v. Royer (1983) e, nesta oportunidade, foi aplicada como fundamento para a decisão do caso concreto. Notou-se que há circunstâncias que "certamente denotam uma demonstração de autoridade suficiente para que 'uma pessoa razoável acreditaria que não está livre para ir embora (United States v. Mendenhall [...])"'64. Ressaltou-se, então, que "policiais não violam a Quarta Emenda por meramente se aproximar de um indivíduo na rua ou em outro espaço público", contanto que as circunstâncias da abordagem não denotem coercitividade, a qual exige então o cumprimento dos requisitos fixados em Terry para uma stop ${ }^{65}$.

\footnotetext{
${ }^{62}$ United States v. Mendenhall, 446 U.S. 544 (1980)

${ }^{63}$ United States v. Mendenhall, 446 U.S. 545 (1980), tradução livre. A regra, contudo, não foi utilizada para solucionar o caso pela maioria dos Justices, por falta de prequestionamento nas instâncias inferiores

${ }^{64}$ Florida v. Royer, 460 U.S. 502 (1983), tradução livre. No caso, os policiais abordaram o acusado (Royer) em um aeroporto, identificaram-se como investigadores de tráfico de drogas e informaram ao abordado que ele era suspeito de transportar drogas. Após, pediram para acompanhá-los até a sala do polícia, retiveram seus documentos e não indicaram de qualquer modo que ele estava livre para embarcar.

${ }^{65}$ Florida v. Royer, 460 U.S. 497 (1983), tradução livre.
}

Revista de Direito Brasileira | Florianópolis, SC | v. 24 | n. 9 | p.341-364 | Set./Dez. 2019 
Além de diferenciar um encounter de uma stop, também a própria extensão de uma stop em relação a detenções mais gravosas foi delimitada pela Corte em outros julgados após Terry. Assim, em Davis v. Mississippi (1969) ${ }^{66}$ e em Dunaway v. New York (1979) ${ }^{67}$, a condução de suspeito à delegacia para interrogatório e coleta de digitais foi reputada mais gravosa do que mera stop e, por isso, dependente de causa provável. Seguindo essa orientação restritiva, em 1982, no caso United States v. Place ${ }^{68}$, a Corte decidiu que uma detenção de cerca de 90 minutos não se enquadraria como uma retenção (stop) e demandaria, pois, mandado prévio ${ }^{69}$. Além disso, ressaltou-se ser desarrazoada stop em que os policiais não indicam aonde levarão os bens apreendidos, nem por quanto tempo e de que modo serão devolvidos.

\subsection{Precedentes relativos à frisk}

Além dos precedentes relativos à delimitação de uma stop, outros casos foram importantes para delimitar a extensão e a finalidade de uma frisk. No caso Ybarra v. Illinois ${ }^{70}$ (1979), ressaltouse que a frisk tem finalidade protetiva e não investigativa e depende da suspeita individualizada do porte de $\operatorname{armas}^{71}$ :

Nada em Terry pode ser entendido como uma permissão para uma generalizada "busca rápida por armas", nem para quaisquer buscas em procura de qualquer coisa que não sejam armas. O "limitado escopo" da exceção Terry não permite uma revista por armas baseada em menos do que a crença ou suspeita razoável dirigida à pessoa a ser revistada, mesmo que esta pessoa esteja em um recinto em que está ocorrendo uma busca por narcóticos ${ }^{72}$.

\footnotetext{
${ }^{66}$ Davis v. Mississippi, 394 U.S. 721 (1969)

${ }^{67}$ Dunaman v. New York 442 U.S. 201 (1979). Decidiu-se que uma "detenção para interrogatório sob custódia independentemente de sua nomenclatura - constitui uma intrusão tão severa nos interesses protegidos pela Quarta Emenda a ponto desencadear a exigência das garantias tradicionais contra a prisão legal”. Nesse passo, a Corte salientou que a condução coercitiva de Dunaman à delegacia não poderia ser sustentada com base no entendimento fixado em Terry, pois não configurou uma mera "stop and frisk', mas sim um ato substancialmente indiscernível de uma prisão (arrest), a qual exige causa provável.

${ }^{6} 462$ U.S. 696 (1983). Além disso, nesse caso, ressaltou-se ser desarrazoada uma stop and frisk em que os agentes executores não respondem adequadamente aonde levarão os bens apreendidos, por quanto tempo, e de que modo os bens serão devolvidos ao abordado.

${ }^{69}$ Nesse sentido, a Corte já ressaltou, em mais de uma oportunidade, a necessidade de obtenção de um mandado judicial prévio para a realização de uma busca mais invasiva do que uma mera stop and frisk. Illinois v. McArthur, 531 U.S. $\underline{326 \text { (2001); United States v. Sokolow } 490 \text { U.S. } 1 \text { (1989) }}$

70444 U.S. 85 (1979)

${ }^{71}$ Ybarra v. Illinois 444 U.S. 86 (1979). Nesse caso, um juiz expediu um mandado que autorizava busca em taverna cujo dono era suspeito de possuir heroína. Ao entrar na taverna, a polícia avisou a todos os presentes que realizariam uma rápida busca por armas. Entre outros, Ybarra, um consumidor, foi revistado por um policial que sentiu um pacote de cigarros com objetos, no interior do qual encontrou pacotes de heroína. A Suprema Corte ressaltou que a causa provável que embasou a expedição do mandado somente se referia ao porte de heroína por parte do dono da taverna, e não por parte de qualquer consumidor da taverna. Notou que, quando os policiais foram à taverna executar o mandado, nenhum fato lhes permitiu concluir que Ybarra tivesse cometido, estivesse cometendo ou estivesse prestes a cometer qualquer delito. Além disso, não seria possível sustentar que a revista de Ybarra seria uma protetiva por armas (frisk), sob a doutrina fixada em Terry, pois não havia "fato específico que teria justificado um policial na cena a sequer suspeitar que o apelante estivesse armado e fosse perigoso". Similarmente, em Adams v. Williams, 407 U. S. 143 (1972), ressaltou-se que "o propósito dessa limitada revista [permitida em Terry] não é descobrir provas de crime, mas sim permitir ao policial a continuidade da investigação sem medo de violência, e por isso a revista em procura de armas pode ser necessária e razoável independentemente de o porte de arma oculta ser ou não proibido sob a lei estadual aplicável. Contanto que o policial esteja autorizado a realizar uma abordagem forçada (forcible stop), ele poderá conduzir uma limitada busca por armas, limitada a tal propósito protetivo" (tradução livre). No mesmo sentido: Pennsylvania v. Mimms, 434 U. S. 106 (1977).

${ }^{72}$ Ybarra v. Illinois 444 U.S. 93-94 (1979), tradução livre.
}

Revista de Direito Brasileira | Florianópolis, SC | v. 24 | n. 9 | p.341-364 | Set./Dez. 2019 
Nesse sentido, no caso Arizona v. Hicks (1987), firmou-se que a frisk deve ter substrato em fatos "que garantam razoavelmente ao policial que o suspeito é perigoso e pode assumir imediato controle de armas"73. Assim, observou-se que a suspeita razoável é bastante para realizar uma revista de finalidade protetiva (frisk), mas uma busca de finalidade investigativa sempre exige causa provável ${ }^{74}$. Quanto ao ponto, já no caso Adams v. Williams (1972), a Corte ressaltou que a validade da frisk depende da estrita limitação à procura por arma com base em uma suspeita objetiva que lhe dê suporte ${ }^{75}$.

Nessa linha, no caso Minnesotta v. Dickerson (1993), a Corte realçou que, se o policial, ao proceder a uma frisk, não descobre nada que possa ser uma arma, não pode continuar revistando o indivíduo a fim de tentar obter e apreender drogas que suspeita que o revistado possua em seu bolso. Nesse caso, a apreensão só poderia ocorrer se a posse de drogas fosse imediatamente aparente, detectada pelo mero toque (em aplicação da plain view exception $)^{76}$.

\subsection{Precedentes ampliativos e desfuncionalização: da indefinição conceitual ao uso da stop and frisk como tática de policiamento preventivo}

O objetivo de delimitação estrita dos elementos que definem a stop and frisk e que validam a atuação policial sem causa provável e sem mandado, identificado em Terry e em outros precedentes da Suprema Corte, não foi seguido à risca. Outros casos posteriores julgados da própria Suprema Corte e de tribunais de instâncias inferiores revelaram a dificuldade de definição de uma stop and frisk e de seus requisitos de validade.

Saltzburg e Capra (1996, p. 168) observam então que é difícil superestimar o impacto do caso Terry sobre toda a jurisprudência posterior sobre a Quarta Emenda, pois o caso abriu uma brecha para que a exigência de mandado fosse mitigada e sobreposta pela análise da razoabilidade da busca/detenção - mesmo em casos em que não se estivesse diante de stop and frisk, mas de intervenção mais gravosa.

Com efeito, embora a Suprema Corte tenha inicialmente indicado em Terry que a stop and frisk seria uma abordagem breve e pouco intrusiva, motivada pela suspeita razoável da prática de uma infração penal e limitada pela busca por armas, tais parâmetros foram flexibilizados pelas cortes sobretudo em casos que envolviam a repressão ao tráfico, no âmbito da chamada "guerra contra as drogas" (war on drugs), anunciada pelo presidente Richard Nixon (1969-1974) e especialmente intensificada por Ronald Reagan (1981-1989) (SALEEM, 1997).

Nesse passo, a exceção à exigência de mandado e causa provável, reservada no caso Terry a stops and frisks breves e superficiais, foi sendo paulatinamente aplicada pelas cortes a detenções mais longas e a intervenções mais ostensivas e intrusivas, especialmente contra o tráfico e mediante

\footnotetext{
${ }^{73}$ Michigan v. Long, 463 U.S. 1033 (1983).

${ }^{74}$ Arizona v. Hicks 480 U.S. 321 (1987). Caso descrito na nota de rodapé n. 23. No entanto, Stephen Saltzburg e Daniel Capra (1996) ponderam que, mesmo após o caso Hicks, continuou a ser arguida perante as cortes inferiores a tese de que buscas investigativas breves podem ser amparadas em suspeita razoável.

${ }^{75}$ Adams v. Williams, 407 U.S. 151 (1972). Em voto vencido, o Justice Brennan chegou a observar que a possibilidade de atuação com base em suspeita razoável não deveria se aplicar aos crimes de posse/porte de drogas, pois traria o risco de que a revista (frisk), em vez de ser protetiva e meramente incidental à retenção (stop), acabasse se tornando a própria finalidade da retenção e assumisse instrumentalidade investigativa e não protetiva

${ }^{76}$ Minnesotta v. Dickerson, 508 U.S. 366-367 (1993), tradução livre. Ao comentar a importância do caso, Hemmens e Carmen salientam que se trata de uma decisão complementar ao caso Sibron, em que havia sido frisada a finalidade protetiva da revista (frisk). Apontam: "Definir os limites aplicáveis é importante como um guia para o trabalho policial a fim de prevenir arbitrariedade e abuso. Ausentes parâmetros claros e bem definidos, a revista de uma pessoa pode facilmente se tornar uma "expedição de pescaria" em busca de provas pela polícia. O potencial de abuso é enorme e pode ser perverso, daí a necessidade de controle. A Corte em Dickerson enviou esta mensagem: as revistas (frisks) possuem uma finalidade limitada. Qualquer intervenção para além da proteção policial é proibida". (2010, p. 81, tradução livre).
} 
força policial, imobilizações, armas e algemas (SALEEM, 1997) ${ }^{77}$. Com isso, a própria definição de stop and frisk tornou-se nebulosa.

Nesse sentido, para Williamson (1982), a Corte não forneceu parâmetros definitivos para definir quando ocorre uma detenção (seizure) sob a modalidade de uma "stop". Como visto, no caso Terry, fixou-se que, "sempre que um policial aborda um indivíduo e restringe a sua liberdade de ir embora, ele 'deteve' esse indivíduo" e que uma detenção "ocorre sempre que um agente policial 'por meio de força física ou demonstração de autoridade' restringe de alguma maneira a liberdade de um cidadão". Não obstante, Williamson (1982) destaca que é difícil conjecturar uma interação entre um policial e um suspeito que não constitua uma stop, pois, como a Corte reconhece, "qualquer interrogatório de um suspeito por um policial terá um elemento coercitivo, simplesmente pelo fato de que o policial é parte de um sistema de imposição legal que pode em última instância submeter o suspeito à persecução penal"78.

Nesse passo, disseminaram-se opiniões favoráveis à prática difusa e irrestrita da stop and frisk como medida de prevenção à criminalidade, a partir do abandono das diretrizes fixadas no caso Terry. Nesse sentido são as manifestações, por exemplo, de James Wilson e Lawrence Sherman. Este, fundamentando-se em pesquisa realizada em Kansas, aduziu que abordagens estrategicamente realizadas em locais de alta criminalidade podem reduzir crimes com arma de fogo, ao aumentar as apreensões de armas ilegais (SHERMAN; SHAW; ROGAN, 1995). Contudo, Sherman desconsidera a quantidade de abordagens a inocentes e a desproporção entre negros inocentes e brancos inocentes abordados - para cada arma apreendida durante a pesquisa, pelo menos vinte e sete revistas foram realizadas em face de inocentes, os quais, em sua esmagadora maioria, eram negros (SCHWARTZ, A., 1995, p. 319-322).

Trilhando orientação similar, James Q. Wilson (1994) aponta que o método mais efetivo de coibir o porte ilegal de armas de fogo é por meio da prática generalizada de stops and frisks no espaço público. Wilson (1994) defende então a admissão de abordagens generalizadas, pois estas seriam tornadas raras quando os policiais se confrontam com a preocupação de suas revistas serem invalidadas em função do não cumprimento de parâmetros constitucionais ou de serem acusados de abuso de autoridade. Para Wilson, essa preocupação desencoraja as abordagens e contribui para a ineficácia do controle de armas de fogo no país e, consequentemente - segundo a sua teoria das janelas quebradas (broken windows theory $)^{79}$-, para o aumento geral da criminalidade no país. Nesse sentido, Wilson aponta que o fato de que pessoas inocentes serão abordadas, e de que minorias étnicas provavelmente o serão mais frequentemente, é problemático apenas pelo risco de criação de uma tensão conflituosa entre a comunidade minoritária e o aparato policial (SCHWARTZ, A., 1995). Assim, o problema é enfrentado pela perspectiva da ordem e da estabilidade social, sem preocupação com a sistemática violação de direitos decorrente de práticas institucionalizadas de discriminação.

Esse uso generalizado da stop and frisk como tática de policiamento urbano implica a desfuncionalização da medida - assim como detectado no cenário brasileiro (cf. WANDERLEY, 2017). Com efeito, tal como formatada pela Suprema Corte no caso Terry, a stop tem função investigativa e a frisk tem função protetiva e associa-se a uma situação particularizada e individualizada em que a intervenção policial é necessária. No entanto, ao transmudar-se em

\footnotetext{
${ }^{77}$ Confiram-se, ilustrativamente: United States v. Saffeels, 510 U.S. 801 (1993) - algemas; United States v. Clipper, 973 F.2d 944 (D.C. Cir. 1992) - armas apontadas; United States v. Esieke, 940 F.2d 29 (2d Cir. 1991) - algemas nos braços e pernas. Nesse sentido, Saltzburg e Capra (1996) notam que a exigência de causa provável para buscas investigativas foi ignorada pelas cortes estadunidenses mesmo após o caso Arizona v. Hicks (1987).

${ }^{78}$ Oregon v. Mathiason, 429 U.S. 495 (1977), tradução livre.

${ }^{79}$ Wilson é coautor, juntamente com George Kelling, da broken windows theory (teoria das janelas quebradas), com cujas premissas parece coadunar-se a sua defesa da propagação da stop and frisk. Segundo esta teoria, o Estado deve esforçar-se monitorar ostensivamente o espaço público, de modo a prevenir o vandalismo e pequenos delitos com o objetivo de evitar crimes mais graves.
} 
mecanismo rotineiro de policiamento, tal como defendido por Sherman e Wilson, passa a visar à função de prevenção geral.

Com a indefinição do conceito, dos requisitos e das finalidades de uma stop and frisk, abriu-se espaço para stops and frisks com base em fundamentos vagos e pretextuais de modo rotineiro, o que, sobretudo, deu margem à filtragem racial (racial profiling) ${ }^{80}$. Quanto ao ponto, Fyfe (1998) observa que o uso arbitrário e discriminatório da stop and frisk figura entre as reclamações mais persistentes dos cidadãos em relação à conduta policial, em especial daqueles residentes em áreas periféricas. De fato, após o caso Terry, a filtragem racial tem sido associada à stop and frisk (AMAR, 2005) e "encontros investigativos" com a polícia têm encetado tensão e ressentimento entre a juventude negra nos EUA (WALKER, 1993).

Com efeito, no caso Terry, a Corte deixou de estabelecer qualquer exigência ou imposição direcionada a impedir ou reduzir a discriminação racial generalizada por parte do aparato policial no país e rejeitou a exclusionary rule como meio de desestimular abordagens discriminatórias ${ }^{81}$. A aplicação posterior do precedente, por sua vez, encetou o alargamento paulatino da definição e dos requisitos de uma stop and frisk, dificultando o controle judicial e abrindo espaço para a reprodução de preconceitos.

Dois outros julgados da Corte após Terry são especialmente criticados em virtude da abertura para a prática de abordagens racialmente direcionadas. Ainda em 1975, em United States v. Brignoni-Ponce, relativo a um caso de fiscalização de imigração, a Suprema Corte assentou que a raça do indivíduo poderia ser um fator para a formação de uma suspeita razoável, desde que não fosse o único ${ }^{82}$. Na oportunidade, a Corte assentou que "qualquer número de fatores pode ser levado em consideração para decidir se há suspeita razoável para parar um veículo em área de fronteira" e que a aparência racial é um fator relevante.

Nesse julgamento, o Justice Douglas (vencido em Terry) ressaltou que apenas enumerar alguns fatores a serem considerados, "sem a tentativa de explicar qual combinação de fatores é necessária" para formar uma suspeita razoável, pode simplesmente induzir a polícia a manipular a linguagem e justificar a abordagem com base em uma série de fatores cujo significado probatório é insignificante. O Justice observou então que, em Brignoni-Ponce, a Corte estaria estendendo o “teste da suspeita" fixado em Terry para permitir a intrusão policial em face de uma multiplicidade de inocentes, "cuja única transgressão poderia ser uma aparência ou atitude desconforme

\footnotetext{
${ }^{80}$ Saleem (1997) destaca que era pensamento corrente entre os estadunidenses a noção de que os negros e pobres careceriam do suporte moral e da estrutura familiar necessárias para que se transformem em membros produtivos da sociedade, razão pela qual sucumbiriam ao mercado ilícito de entorpecentes.

${ }^{81} \mathrm{O}$ problema da filtragem racial na prática da stop and frisk não passou totalmente despercebido no caso Terry. Nele, a National Association for the Advancement of Colored People (NAACP) habilitou-se como amicus curiae e argumentou perante a Corte que a admissão de detenções e buscas sem causa provável teria inarredável reflexo para a população negra do país, já vítima de abordagens abusivas. A Corte concordou com a premissa fática apresentada pelo NAACP, no sentido de que as polícias frequentemente discriminam os negros. No entanto, alegou que fixar requisitos de validade mais rígidos para a stop and frisk importaria em aplicação mais rígida da exclusionary rule, o que não seria uma solução adequada para o problema da filtragem racial ou do racismo institucional nas polícias. Para tanto, a Corte alegou que os policiais não praticam abordagens unicamente com o objetivo de produzir prova contra abordado, de modo que a exclusão das provas ilícitas nem sempre teria efeito dissuasório. Além disso, argumentou que aplicar de modo mais rígido a exclusão da prova ilícita teria um profundo efeito adverso em relação à eficácia da repressão criminal. Assim, a Corte ressaltou que as cortes (o Judiciário em geral) não teriam poder suficiente para se opor à filtragem racial e só poderia julgar os casos com os quais se deparasse em cada processo (Terry v. Ohio, 392 U.S. 1415, 1968). Cf. WANDERLEY, 2016.

${ }^{82}$ United States v. Brignoni-Ponce, 422 U.S. 873 (1975). Para além dessa concepção, no caso United States v. Martinez-Fuerte, 428 U.S. 543 (1976), a própria necessidade de demonstração da suspeita razoável foi abandonada, pois tida como "impraticável" na situação analisada, de revistas em locais predeterminados e fixos, como em aduaneiras (checkpoint stops). No caso, entendeu-se que basta para a abordagem a mera constatação da aparência racial dos suspeitos (supostos mexicanos). Para justificar essa posição, a Suprema Corte fez menção a um balanceamento entre o interesse público e as garantias individuais, em que o primeiro possuiria prevalência.
} 
(nonconformist)", o que traz "um estado de coisas em que a polícia pode reter cidadãos na rua com base na mais frágil das justificativas" 83 .

Para o Justice Douglas, no julgamento de Terry, a maioria vencedora tinha a esperança de que a exceção então estabelecida só seria empregada na repressão a crimes violentos, expectativa que, contudo, não foi confirmada nos anos posteriores:

Os receios que eu expressei em Terry, sobre o enfraquecimento da Quarta Emenda, foram lamentavelmente corroborados pelos eventos subsequentes. A esperança de que o "teste da suspeita" (suspicion test) seria empregado apenas na persecução ao crime violento - uma limitação defendida por alguns de seus proponentes - foi agora esmagada, uma vez que ele tem sido aplicado a investigações relativas a narcóticos, na apreensão de imigrantes "ilegais", e até mesmo tem sido considerada um construto legal para a regulamentação de um poder policial investigatório geral. ${ }^{84}$

O Justice Douglas realçou então que, se o "teste da suspeita" de fato tem alguma aptidão para restringir o poder policial, ela só poderia decorrer do controle judicial vigoroso da sua aplicação, e não apenas da linguagem utilizada nas decisões da Corte.

Por outro lado, anos mais tarde, em 1996, no julgamento de Whren v. United States ${ }^{85}$, a Corte procedeu a novo alargamento dos poderes policiais. No caso, Whren e Brown dirigiam em uma "área de tráfico" (high drug area). Policiais à paisana, que patrulhavam a vizinhança em um veículo não identificado, perceberam Whren e Brown parados ante o semáforo de um cruzamento por tempo reputado excepcionalmente longo (mais de vinte segundos). De súbito, sem dar seta, Whren acelerou e fez a curva. Ao observar essa infração de trânsito, os policiais pararam o veículo e, quando se aproximaram, viram Whren carregando sacolas com crack.

A Corte, em opinião redigida pelo Justice Antonin Scalia, entendeu que, se havia suspeita razoável da prática de infração de trânsito, a abordagem é lícita, independentemente da intenção que efetivamente motivou o policial a realizar a abordagem ${ }^{86}$. A Corte, então, admitiu a prática de abordagens com base em fundamentos meramente pretextuais, abrindo espaço à filtragem racial (racial profiling).

Tal o panorama, é imperioso reconhecer que, nas décadas subsequentes ao caso Terry, a despeito da preocupação inicial da Corte em delimitar uma exceção estrita à Quarta Emenda, as normas atinentes às abordagens policiais no espaço público tornaram-se nebulosas e imprecisas, em virtude do posicionamento vacilante da própria Suprema Corte e das instâncias judiciais inferiores. Com isso, tornou-se reduzida a possibilidade de os cidadãos oporem seus direitos constitucionais diante da coerção policial, visto que a sua validade se tornou dependente de critérios maleáveis e confusos, suscetíveis de inúmeras interpretações conflitantes.

\section{A IMPORTÂNCIA DO CONTROLE JUDICIAL DA ATIVIDADE POLICIAL: VISÃO DA SUPREMA CORTE E DA DOUTRINA ESTADUNIDENSES}

\footnotetext{
${ }^{83}$ United States v. Brignoni-Ponce, 422 U.S. 890 (1975), tradução livre.

${ }^{84}$ United States v. Brignoni-Ponce, 422 U.S. 888-889 (1975), tradução livre.

85517 U.S. 806 (1996)

${ }^{86}$ Utilizou-se fundamentação diversa daquela utilizada em outros precedentes para firmar a "exceção da boa-fé" (good faith exception), segundo a qual, mesmo se estiver objetivamente ausente causa provável para a prática de uma busca/prisão, se o policial age movido de boa-fé, deve ser reconhecida a sua licitude. Cf. United States v. Leon, 468 U.S. 897 (1984); Massachussets v. Sheppard 468 U.S. 981 (1984); Herring v. United States, 555 U.S. 135 (2009). Em sentido contrário, embora em obiter dictum, veja-se Horton v. California, 496 U.S. 128 (1990).
} 
Em Ornelas v. United States (1996) ${ }^{87}$, a Suprema Corte reforçou o entendimento de que a questão referente à configuração de suspeita razoável para a prática de uma stop e à configuração de causa provável para a prática de uma busca (search) deve ser submetida ao controle judicial, inclusive em grau de apelação (de novo review) ${ }^{88}$. E, na segunda instância, as cortes podem reexaminar o acervo fático-probatório dos autos e utilizar premissas diversas daquelas utilizadas pelo juízo inferior na decisão recorrida.

A Corte realçou, então, a importância do controle judicial das práticas policiais e da reanálise da questão pelas cortes de segunda instância, uma vez que a uniformização de precedentes evitaria interpretações diversas a fatos similares: se as cortes mantiverem controle e esclarecerem as regras legais pertinentes, os precedentes poderão fornecer à polícia "um arsenal definido de regras que, na maior parte dos casos, tornarão possível definir corretamente de antemão se uma determinada invasão da privacidade é justificada no interesse do law enforcement". Ressaltou-se que os principais componentes da revisão de novo da configuração da suspeita razoável/causa provável são "(1) a definição dos fatos que ensejaram a stop ou search, e (2) a decisão sobre questão mista, de fato e de direito, sobre se tais fatos, a partir da perspectiva de um policial objetivamente razoável, são suficientes para configurar suspeita razoável ou causa provável"89.

Ante tal importância do controle judicial das práticas policiais, reconhecida pela Suprema Corte, é certo que a flexibilização excessiva de definições e requisitos das intervenções policiais torna o controle judicial inefetivo e dá margem à realização de abordagens arbitrárias, calcadas em percepções e induções discriminatórias. Por isso, o controle judicial da atividade policial deve assentar em diretrizes firmes e claras que permitam coibir atos abusivos, mas, ao mesmo tempo, não cerceiem o poder policial de investigar e interromper práticas dotadas de aparência criminosa.

Nesse sentido, é interessante pontuar que a stop and frisk é uma prática policial que, muito antes de 1968, já fazia parte do cotidiano do policiamento nos Estados Unidos e era considerada como uma parte essencial e necessária do policiamento (HEMMENS; CARMEN, 2010). Portanto, mesmo antes do julgamento do caso Terry, esse tipo de abordagem policial já era praticada pelas polícias estadunidenses e, inclusive, já era objeto de regulamentação na esfera estadual e de debate jurídico (cf. SOWLE, 1962; KUH, 1965; SCHWARTZ, H., 1967).

James J. Fyfe aduz então que há uma opinião unânime entre os policiais - com a qual ele concorda - no sentido de que "a autoridade de deter, questionar e, onde houver perigo aparente, revistar pessoas suspeitas é uma parte indispensável do seu trabalho" (1998, p. 1.231). Para reforçar seu argumento, Fyfe (1998) debruça-se sobre o caso Terry v. Ohio e analisa as alternativas ao alcance do policial McFadden naquela situação fática. Observa que, se este se omitisse por completo diante da suspeita da prática iminente de assalto à mão armada, estaria arriscando uma intervenção letal após o início da execução do delito. Por outro lado, se abordasse os indivíduos, mas não efetuasse a revista, estaria arriscando receber uma resposta letal às perguntas direcionadas aos três abordados. Conclui, então, que McFadden não tinha nenhuma escolha real senão a de proceder como procedeu, mediante retenção e revista (stop and frisk) dos suspeitos de assalto iminente.

Noutro giro, Fyfe (1998) remete às práticas da Special Investigation Section do Los Angeles Police Department (SIS/LAPD) a fim de explicitar que a exigência de causa provável para toda e qualquer abordagem coercitiva, com a correlata proibição da stop and frisk com base em suspeita razoável, poderia legitimar e incentivar intervenções deliberadamente violentas e letais. Fyfe nota que chegou a vigorar na SIS/LAPD uma diretriz de não-intervenção enquanto houvesse apenas suspeita razoável (e não causa provável). A partir dela, os policiais seguiam os suspeitos,

\footnotetext{
87517 U.S. $690(1996)$

${ }^{88}$ A “de novo review" é um parâmetro amplo de revisão judicial, no qual o tribunal de segunda instância pode reanalisar tanto as questões fático-probatórias, quanto as questões eminentemente jurídicas do caso, sem qualquer deferência às premissas firmadas pelo juízo inferior prolator do primeiro julgamento.

${ }^{89}$ Ornelas v. United States, 517 U.S. 690 (1996) (tradução livre).
}

Revista de Direito Brasileira | Florianópolis, SC | v. 24 | n. 9 | p.341-364 | Set./Dez. 2019 
observavam-nos em atos preparatórios de delitos e confrontavam-nos apenas na fase de execução do crime. Assim, não se realizava uma retenção investigativa a fim de justificar uma intervenção letal posterior, acobertada por situação de legítima defesa ${ }^{90}$.

Esse caso evidencia que a realização de uma stop and frisk investigativa e protetiva, com suporte em suspeita razoável, conforme autorizado pela Suprema Corte em Terry v. Ohio, permite interromper a prática delitiva nos estágios iniciais e evitar, assim, uma reação letal em face de um crime violento em estágio avançado de execução.

Nesse sentido, Fyfe (1998, p. 1.240) nota que os policiais retêm (stop) indivíduos em duas situações: a partir da suspeita particularizada de um crime específico, ou a partir de uma suspeita genérica de que a pessoa é, no vernáculo policial, "errada" ou "suja". Fyfe (1998, p. 1.241) aponta que apenas o primeiro tipo de retenção (investigativa) foi autorizado em Terry, mas é comumente confundido com o segundo. Assim, as retenções, que deveriam visar à investigação de um delito, são usadas para assediar pessoas ou garantir que não saiam das áreas às quais os policiais acreditam que elas "pertencem".

Quanto ao ponto, Jon Gould e Stephen Mastrofsky (2004) alertam que retenções inconstitucionais (do segundo tipo) são feitas a partir de um filtro seletivo embasado em características do suspeito. Por isso, pessoas com menor poder social, político ou econômico estão sob maior risco de retenções ilegais. A desfuncionalização da medida, então, é acompanhada por um incremento do risco de incidência discriminatória, viabilizado pela vagueza da suspeição que ampara as retenções do segundo tipo.

Nesse cenário, após observação direta de 115 (cento e quinze) buscas em face de transeuntes $^{91}$, Gould e Mastrofsky (2004) aferiram que, mesmo usando parâmetros conservadores, cerca de um terço das buscas não cumpriram os requisitos mínimos de constitucionalidade, aproximando-se das retenções do segundo tipo. Contudo, quase nenhuma delas foi visível ao Judiciário ${ }^{92}$, o que, para os autores, permite que os policiais levem a Quarta Emenda "ao limite" ou mesmo para além do legalmente permissível.

90 "Em um caso do SIS, por exemplo, a unidade policial seguiu quatro suspeitos de assalto até um Restaurante McDonald's, assistiu-lhes durante várias horas enquanto eles rodeavam a loja até esta fechar e nela restar só uma gerente de 24 anos. O SIS observou enquanto os suspeitos colocaram máscaras de ski, caminharam ao lado da loja e chutaram a porta. Quanto a gerente, apavorada, chamou o 911, o SIS cancelou as chamadas por viaturas e esperou do lado de fora enquanto os assaltantes ameaçaram-na com armas (que na verdade eram de brinquedo), tamparam a sua boca, braços, pernas com fita, colocaram-na em um refrigerador e abriram o cofre. Quando os assaltantes saíram e entraram no carro, o SIS usou dois carros não identificados para bloquear a saída dos assaltantes, matando três e ferindo um, com 226 disparos de revólver e pistola. Ao excluir a possibilidade de realizar uma rápida Terry stop para prevenir tal chacina, o Chefe de Polícia do LAPD Daryl Gates disse: 'Se eles [o SIS] tivessem os retido do lado de fora [do restaurante antes que eles entrassem], eles [os suspeitos] estariam livres por fiança hoje, e provavelmente roubando outra pessoa... Agora não haverá mais nenhum desses assaltos no McDonald's. Talvez nós tenhamos conseguido algo"”. (FYFE, 1998, p. 1.242, tradução livre)

${ }^{91}$ Nenhuma das buscas foi precedida de mandado. Em uma, aborda-se ciclista que corresponderia à descrição de suspeito de tráfico de drogas concedida por denunciante anônimo. O ciclista nega envolvido com o tráfico, mas os policiais revistam-no extensivamente, incluindo testículos e ânus. Ao fim, nada encontram em seu desfavor.

92 Mesmo antes do julgamento de Terry, a inclusão do § 180-a no NY Criminal Procedure Code, em 1964, já havia suscitado a questão da dificuldade do controle judicial da stop and frisk, cuja baixa visibilidade ao Judiciário poderia encetar uma ampla gama de abusos do poder policial (SCHWARTZ, H., 1967). A pesquisa de Gould e Mastrofsky confirmou esse receio. Ao analisar os resultados da pesquisa de Gould e Mastrofsky, Fyfe (2004) ressalta que é demasiado alto o percentual de $30 \%$ de buscas inconstitucionais. Observa que, embora a violação da lei seja comumente justificada pela suposta dificuldade de observância das normas aplicáveis, estas não são complicadas (2004, p. 380). Gould e Mastrofsky (2004, p. 316-318), de sua parte, relacionam o alto número de buscas inconstitucionais ao encorajamento à proatividade encetada pelo policiamento comunitário e pela guerra às drogas, as quais se imiscuem em táticas de "manutenção agressiva da ordem" que são "sensíveis em relação à Bill of Rights" (2004, p. 318). Ponderam que as buscas inconstitucionais não foram feitas por policiais alinhados ao estereótipo do policial predisposto a desobedecer às leis ("Dirty Harry”). Ao contrário, eram policiais-modelo que expressaram o desejo de tratar bem todos os cidadãos, incluindo os suspeitos. As ilegalidades eram então vistas como intervenções normais e não foram questionadas pela hierarquia policial, pelos tribunais, ou pela sociedade.

Revista de Direito Brasileira | Florianópolis, SC | v. 24 | n. 9 | p.341-364 | Set./Dez. 2019 
A esse respeito, Fyfe (1998) argumenta então que o controle de validade da stop and frisk não é simplório. Destaca a dificuldade de controlar a falsidade do depoimento dos policiais e o apoio popular a medidas policiais ilegais. Por isso, defende que o melhor modo de limitar a discricionariedade policial não seria mediante controle judicial, mas pela regulamentação administrativa e pela imposição de disciplina pelas próprias polícias.

Os fatos apresentados por Fyfe, contudo, não deixam dúvida sobre a importância da aplicação concomitante do controle judicial em relação aos demais mecanismos de controle da polícia. Fyfe (1998) observa que o caso Terry v. Ohio teve pouco impacto nas ações do New York Police Department (NYPD), pois desde 1964 a prática da stop and frisk já era regulada na legislação estadual nova-iorquina. Quanto à lei, Fyfe (1998) nota que havia um reconhecimento de que sua constitucionalidade poderia ser questionada judicialmente, razão pela qual foram construídas diretrizes para limitar e conter esse poder policial. Assim, embora a lei possuísse apenas dois breves parágrafos, cinco páginas de exigências, limitações, proibições e exemplos foram utilizadas para regulamentar a lei, blindando-a de questionamentos judiciais. Nesse passo, nota-se que foi exatamente a perspectiva do controle judicial de validade que impeliu as polícias a, de antemão, delimitar o exercício de seu poder, resguardando a validade da própria lei.

Por outro lado, embora Fyfe (1998) ressalte a importância dos sistemas de recompensa e disciplina internos às corporações policiais como método de controle da atuação policial, ele próprio destaca que os chefes de polícia preferem a ambiguidade quanto à esfera de intervenção lícita de seus subordinados e não visualizam efetivo prejuízo em abordagens ilegais, as quais serviriam para demonstrar que os policiais estão "fazendo o seu trabalho". Por isso, o controle interno mostra-se por si só insuficiente para garantir a legalidade das abordagens policiais.

Fyfe (1998) anota, ademais, que o NYPD possui um formulário de registro das stops and frisks (UF-250), que, contudo, não é utilizado como um instrumento de controle de constitucionalidade da medida, mas sim como instrumento de monitoramento da presença de determinados suspeitos em alguns locais ${ }^{93}$. Assim, esse mecanismo de controle interno elaborado pelas próprias polícias não têm sido espontaneamente por elas aproveitado para fiscalizar a observância dos requisitos de validade das stops and frisks, mas apenas para fiscalizar a eficiência do direcionamento de tais intervenções.

Tal aspecto, é interessante notar, foi salientado na decisão da class action Floyd, et al. v. City of New York, et $a l^{94}$, proferida em 2013 pela juíza federal Shira Scheindlin, da Corte Federal do Distrito Sul de New York, na qual se reconheceu a inconstitucionalidade da política de stops and frisks do NYPD entre 2004 e 2012. Na decisão da referida class action, reconheceu-se a fragilidade dos fundamentos utilizados pelos policiais para fundamentar as abordagens, e também, a partir dos dados do próprio NYPD, o direcionamento racial de tais abordagens. Notou-se então que o NYPD não tem exigido o cumprimento efetivo das condições de validade das stops and frisks exigidas pela Suprema Corte, bem como não tem estabelecido quaisquer medidas para coibir a filtragem racial (cf. WANDERLEY, 2016).

Ante tais aspectos, observa-se que, sem a contraposição judicial às arbitrariedades policiais, não há como esperar que as próprias polícias delimitem e fiscalizem autônoma e suficientemente o poder de reter e revistar indivíduos nos espaços públicos. A perspectiva de invalidação dos resultados de práticas inconstitucionais por meio do controle judicial é, pois, um

\footnotetext{
${ }^{93} \mathrm{O}$ formulário possui opções objetivas pré-determinadas que devem ser assinaladas em cada caso concreto para identificar as circunstâncias que levaram à abordagem. Há cópia do formulário em RIDGEWAY, 2007, p. 44-45. Ridgeway (2007), assim como Fyfe (1998), ressalta que o UF-250 foi elaborado a partir de uma preocupação com a eficiência da investigação, e não com o controle da sua validade. Nota então que os chefes de polícia exigem que o formulário seja sempre completo e detalhado, mas não há exigência de que toda abordagem seja registrada. Assim, os policiais têm incentivo para documentá-las para demonstrar produtividade, mas podem deliberadamente deixar de documentar aquelas cuja legalidade for controversa.

${ }^{94}$ Floyd, et al. v. City of New York, et al. 959 F. Supp. 2d 540 (2013).

Disponível em: http://www.nysd.uscourts.gov/cases/show.php?db=special\&id=317 Acesso em 15/3/2016
}

Revista de Direito Brasileira | Florianópolis, SC | v. 24 | n. 9 | p.341-364 | Set./Dez. 2019 
elemento central - embora, certamente, não o único - para a sua funcionalização e conformação às diretrizes constitucionais.

\section{CONCLUSÃO}

No atual cenário brasileiro, a prática generalizada de buscas pessoais em face de jovens negros e pobres é vista com naturalidade pela sociedade, pelas polícias e pelas próprias instituições de controle. Admite-se o uso de uma noção vaga de suspeição como fundamento para a busca pessoal, o que permite que seja praticada sem instrumentalidade probatória e a partir de critérios arbitrariamente manipuláveis pelos policiais ${ }^{95}$.

Em contraste com a abordagem tímida conferida à busca pessoal na dogmática jurídica brasileira, a problemática não é subsidiária no cenário jurídico estadunidense. Observou-se neste artigo que a stop and frisk é objeto da atenção da própria Suprema Corte dos EUA desde 1968. Desde então, entende-se que a restrição da liberdade e da privacidade dos indivíduos, ainda que breve e superficial, não pode ser deixada sob escrutínio exclusivo das polícias, mas deve ser submetida ao controle judicial de legalidade. Assim, conquanto com avanços e retrocessos nas orientações prevalentes, contempla-se continuamente o Judiciário como um importante protagonista da delimitação da esfera válida das práticas policiais coercitivas.

Pela análise dos julgados já proferidos pela Suprema Corte estadunidense, a despeito da multiplicidade de entendimentos já proferidos, é possível constatar a constante inadmissão da prática de buscas e apreensões (atos restritivos da liberdade e/ou privacidade individual) de forma generalizada ou simplesmente aleatória. Da mesma forma, não se admite que o critério para a realização de tais medidas seja deixado exclusivamente ao crivo das polícias, incumbidas da sua execução direta. Ao revés, à luz da Quarta Emenda à Constituição estadunidense, verifica-se uma constante preocupação de fixação de critérios objetivos juridicamente controláveis para guiar o exercício de buscas e apreensões.

Portanto, a remissão ao direito estadunidense aponta que é possível estabelecer parâmetros de validade e efetuar controle judicial sobre as abordagens policiais no espaço público. Tal possibilidade, demonstrada pelo recurso ao direito comparado, contraria e desmente a tese de que o exercício do poder policial se assenta em critérios técnicos ("tático-operacionais") impassíveis de qualquer controle judicial. Esta última concepção, que considera que o exercício ou não de determinadas intervenções policiais é questão discricionária cujo mérito é impassível de reexame judicial, não estabelece qualquer empecilho ou óbice ao arbítrio e ao abuso. Por isso, a persistente atuação da Suprema Corte dos EUA evidencia que não é insuperável o atual cenário de fragilidade do controle judicial das práticas policiais no Brasil. Ao revés, à luz dos princípios fundamentais da ordem constitucional democrática inaugurada em 1988, é inadiável reavaliar as possibilidades do controle dessas práticas e, consequentemente, reconsiderar o papel do Poder Judiciário, mormente ante o uso de medidas policiais invasivas, a exemplo da busca pessoal, como medidas de rotina do policiamento ostensivo.

Em tal empreitada, o conhecimento dos julgados da Suprema Corte dos EUA pode ao menos provocar algum estranhamento em relação ao padrão geral de desatenção aos aspectos jurídicos das práticas policiais no Brasil e, assim, pode servir como ponto de partida e estímulo para que temáticas e discussões similares se tornem corriqueiras também no direito brasileiro.

\section{BIBLIOGRAFIA}

AMAR, Paul. Táticas e termos da luta contra o racismo institucional nos setores de polícia e de segurança. In: RAMOS, SILVIA; MUSUMECI, LEONARDA (Org.). . Elemento suspeito:

${ }^{95} \mathrm{Cf}$. WANDERLEY, 2017.

Revista de Direito Brasileira | Florianópolis, SC | v. 24 | n. 9 | p.341-364 | Set./Dez. 2019 
abordagem policial e discriminação na cidade do Rio de Janeiro. Rio de Janeiro: Civilização Brasileira, 2005. .

BAUM, Lawrence. A Suprema Corte americana. Rio de Janeiro: Forense, 1987.

BAYLEY, David H. Padrões de policiamento: uma análise comparativa internacional. São Paulo: Editora da USP, 2001.

FYFE, James J. Stops, frisks, searches, and the Constitution. Criminology \& Public Policy, v. 3 , n. 3, p. 379-396, 2004.

FYFE, James J. Terry: A[n Ex-] Cop's View. St. John's Law Review, v. 72, n. 3, p. 1231-1248, 1998.

GOULD, Jon B.; MASTROFSKY, Stephen D. Suspect searches: assessing police behavior under the U.S. Constitution. Criminology \& Public Policy, v. 3, n. 3, p. 315-362, 2004.

HEMMENS, Craig; CARMEN, Rolando V. Del. Criminal Procedure and the Supreme Court: A Guide to the Major Decisions on Search and Seizure, Privacy, and Individual Rights. Blue Ridge Summit: Rowman \& Littlefield Publishing Group, 2010.

ISRAEL, Jerold H. et al. Proceso penal y Constitución de los Estados Unidos de Norteamérica. Casos destacados Del Tribunal Supremo y texto introductorio. Valencia: Tirant lo Blanch, 2012.

KATZ, Lewis R. Terry v. Ohio at thirty-five: a revisionist view. Mississippi Law Jornal, v. 47, 2004.

KUH, Richard H. Reflections on New York's Stop-and-Frisk Law and its Claimed Unconstitutionality. Journal of Criminal Law and Criminology, v. 56, n. 1, p. 32-38, 1965.

LAFAVE, Wayne R. "Street encounters" and the Constitution: Terry, Sibron, Peters, and beyond. Michigan Law Review, v. 67, n. 1, p. 39-126, 1968.

LEVINSON, Daryl. Rights essentialism and remedial equilibration. Columbia Law Review, v. 99, n. 4, 1999.

MARQUES, Alessandra Garcia. Direitos fundamentais e crise: violência, impunidade, corrupção institucionalizada e o princípio da não culpabilidade no HC n. ${ }^{\circ}$ 126.292/SP do STF. Revista de Direito Brasileira, v. 16, n. 7, 2017, p. 21-42.

NEVES, Marcelo. Transconstitucionalismo. São Paulo: Martins Fontes, 2009.

RIDGEWAY, Greg. Analysis of Racial Disparities in the New York Police Department's Stop, Question, and Frisk Practices. Santa Monica: Rand Corporation, 2007.

SALEEM, Omar. The Age of Unreason: the impact of reasonableness, increased police force, and colorblindness on Terry "stop and frisk". Oklahoma Law Review, v. 50, n. 4, 1997. 
SCHWARTZ, Adina. "Just Take Away Their Guns": The Hidden Racism of Terry v. Ohio. Fordham Urban Law Journal, v. 23, n. 2, p. 317-376, 1995.

SCHWARTZ, Herman. Stop and frisk (A Case Study in Judicial Control of the Police). The Journal of Criminal Law, Criminology and Police Science, v. 58, n. 4, p. 433-464, 1967.

SHERMAN, Lawrence W.; SHAW, James W.; ROGAN, Dennis P. The Kansas City Gun Experiment. In: TRAVIS, JEREMY (Org.). . National Institute of Justice: Research in Brief. U.S. Department of Justice: Office of Justice Programs, 1995. .

SUNDBY, Scott E. Protecting the citizen "whilst he is quiet": suspicionless searches, "special needs" and general warrants. Mississippi Law Jornal, v. 74, 2004.

SUXBERGER, Antonio Henrique Graciano; AMARAL, Marianne Gomes de. A execução provisória da pena e sua compatibilidade com a presunção de inocência como decorrência do sistema acusatório. Revista de Direito Brasileira, v. 16, n. 7, 2017, p. 186-210.

WALKER, Samuel. Taming the system: the control of discretion in criminal justice. New York/Oxford: Oxford University Press, 1993.

WANDERLEY, Gisela Aguiar. Abordagem policial sob suspeita: filtragem racial na "stop and frisk" e controle judicial das práticas policiais a partir dos casos Terry v. Ohio e Floyd v. City of New York. In: BORGES, PAULO CÉSAR CORRÊA; COSTA, RENATA ALMEIDA DA; MENDES, SORAIA DA ROSA (Org.). . Criminologias e política criminal [Recurso eletrônico on-line]. Florianópolis: CONPEDI, 2016. p. 118-138.

WANDERLEY, Gisela Aguiar. Entre a lei processual e a praxe policial: características e consequências da desconcentração e do descontrole da busca pessoal. Revista Brasileira de Ciências Criminais, v. 128, n. 25, p. 115-149, 2017.

WARREN, Samuel D; BRANDEIS, Louis D. The right to privacy. Harvard Law Review, v. 4, n. 5, p. 193-220, 1890.

WILLIAMSON, Richard A. The Dimensions of Seizure: The Concepts of "Stop" and "Arrest". Ohio State Law Journal, v. 43, n. 4, p. 771-818, 1982.

WILSON, James Q. Just take away their guns. The New York Times, 1994. Disponível em: <http://www.nytimes.com/1994/03/20/magazine/just-take-away-theirguns.html ?pagewanted $=$ all \&src $=$ pm $>$. 